\title{
From Pluripotent Stem Cells to Lineage-Specific Chondrocytes: Essential Signalling and Cellular Intermediates
}

\author{
Naoki Nakayama and Katsutsugu Umeda \\ Brown Foundation Institute of Molecular Medicine, \\ The University of Texas Health Science Center at Houston
}

USA

\section{Introduction}

Cartilage is a type of connective tissue found throughout the body. The three major types of cartilage are distinguished by their physical properties, which reflect their relative contents of the extracellular matrices: proteoglycan, elastin fiber and collagen. Hyaline cartilage, which makes smooth joint surfaces at the ends of bone, is hard and translucent. It is rich in type II collagen and hydrophilic proteoglycans, and highly resistance to pressure and shear forces. Elastic cartilage, found in the epiglottis and the Eustachian tube, contains large amounts of elastin fibers throughout the matrix, making it stiff but elastic. Fibrocartilage is often found in areas subjected to frequent compressive stress, such as intervertebral discs and menisci. It contains more collagen (especially type I collagen) and less proteoglycan than hyaline cartilage, enabling fibrocartilage to resist pressure effectively.

Among the many orthopedic conditions, osteoarthritis is one of the most common degenerative joint disorders. Osteoarthritis progresses slowly but steadily to the stage where articular cartilage has to be entirely regenerated or replaced with an artificial joint. Traditional treatments for osteoarthritis deal with the symptoms. While current treatments might offer transient relief of pain, no regenerative therapy has yet been established. Instead, the best available treatment for patients with advanced osteoarthritic disease is surgery to provide an artificial joint. Joint articular cartilage lacks blood vessels and nerves, so damaged cartilage is not spontaneously healed by resident, (if they exist), or nearby (e.g. synovial) chondroprogenitors. In the current climate, chondroprogenitor transplantation is considered a promising therapy for the regeneration of articular cartilage.

Focal damage to articular cartilage, such as that caused by sports injury, can be repaired by regenerative surgery such as the microfracture method, which has been performed for many years. Injured cartilage is removed, subchondral bone is exposed and several tiny holes (microfractures) are created in the bone to cause bone marrow cells and blood to clot and cover the cleared area, thereby promoting healing and tissue repair.

Osteochondral grafting is also performed, in which full-thickness cylindrical plugs of articular cartilage attached to the subchondral bone are directly inserted into matching holes drilled in the chondral defect. Recently, cell-based therapies such as autologous chondrocyte implantation (ACI) have been developed for use in various clinical settings (Brittberg et al., 
1994; Gikas et al., 2009; Moriya et al., 2007; Roberts et al., 2009). ACI involves clearing the damaged site and covering it with a periosteal patch or a collagen membrane, under which expanded articular chondrocytes are placed. ACI therefore requires the sampling of chondrocytes from normal area of the patient's articular cartilage and their expansion in culture to obtain enough cells for treatment. The drawback of the procedure is that in vitro expansion causes de-differentiation of the cells (i.e. loss of chondrocytic phenotypes). Most of the clinical trials of these methods published to date have reported unsatisfactory results. The endogenous marrow cells or implanted de-differentiated chondrocytes used for the microfracture method and ACI, respectively, have shown limited capacity for proliferation and re-differentiation, and tended to produce fibrocartilaginous tissue that fills the cleared, damaged sites or the spaces around the plugs, but is poorly integrated into the surrounding hyaline cartilage. The osteochondral grafting method suffers from a similar integration problem. As a result, the repaired site is often destabilized by tensile and shear forces and lost as a result, leading to the need for subsequent surgery (Steinert et al., 2007).

\section{Stem cells for articular cartilage regeneration}

Chondrocytes developed from endogenous marrow cells or from those once dedifferentiated in vitro apparently fail to make hyaline cartilage matrix in vivo, even after a long-period of time. It is unclear whether the cells of either origin are intrinsically incapable of generating hyaline cartilage, or the environment of diseased/damaged sites is not conducive to the formation of hyaline cartilage. To date, no attempt to overcome the problem has been successful. Furthermore, ACI has the additional drawbacks of 1) requiring the isolation of chondrocytes from the patient's normal cartilage, thereby introducing the long-term risk of the procedure itself inducing a degenerative cartilage disorder, and 2) requiring an effective method, not yet available, for the expansion/dedifferentiation of chondrocytes before transplantation that maintains their redifferentiation capacity. A better source of chondrocytes for joint repair and better knowledge of the critical environmental cues for the development of hyaline cartilage by chondrocytes are clearly needed (Bianco et al., 2008).

\subsection{Adult stem cells}

Mesenchymal stem cells (MSCs), originally isolated from bone marrow (Pittenger et al., 1999), are defined in vitro based on their tri-lineage (i.e. bone, cartilage and fat) differentiation potential and capacity to grow in a clonal fashion (i.e. MSC represents colony-forming unit-fibroblast or CFU-F). Similar cells are known to reside in other adult tissues such as adipose tissue, skeletal muscle, periosteum, synovial membrane, and the dental pulp of deciduous baby teeth (Asakura et al., 2001; De Bari et al., 2001a; De Bari et al., 2001b; Gronthos et al., 2000; Zuk et al., 2002). Since MSCs are capable of proliferating and differentiating into chondrocytes in vitro and in vivo, they were expected to contribute to regenerative therapies for cartilage. However, as for other adult stem cells, the major drawbacks of MSCs for clinical purposes are 1) MSCs are present at low incidence in adult tissues, necessitating in vitro expansion before transplantation, and 2) MSCs have a strong proliferative capacity that diminishes over time; however during proliferation their chondrogenic potential is not stable. As for chondrocytes, these limitations make it difficult to prepare sufficient fully functional MSCs for transplantation. Furthermore, the yield, proliferation capacity, and differentiation potential of MSCs decrease with advancing age, 
limiting the usefulness of clinical application of autologous MSCs in the patient group that would most benefit, namely aged adults (Murphy et al., 2002; Tokalov et al., 2007).

Despite the limitations described, MSCs have been used instead of dedifferentiated chondrocytes for ACI. However, to date, the reported results show that the modified method is no better than conventional ACI in the longer term. The MSC treatment, in combination with growth/differentiation factor-treatment, demonstrates a benefit at 1-2 months, after which the MSC-derived chondrocytes are lost or have matured into hypertrophic chondrocytes that form osteophytes (Steinert et al., 2007).

\subsection{Pluripotent stem cells: embryonic stem cells and induced pluripotent stem cells}

Embryonic stem (ES) cells were first established from the inner cell mass of mouse blastocysts (Evans \& Kaufman, 1981; Martin, 1981). They are described as 'pluripotent' because when injected back into blastocysts, ES cells contribute to all somatic tissues formed during subsequent embryogenesis. Eighteen years later, ES-like cells from human blastocysts were established (Thomson et al., 1998), although their pluripotency has only been inferred based on their teratoma forming activity in immunocompromised mice. Human ES cells have two advantages over adult stem cells for transplantation therapy. They proliferate in culture without the loss of differentiation capacity over a prolonged period, allowing the production of a large number of stem cells. Second, they are theoretically capable of differentiating into any somatic cell types in culture, given the right growth conditions, i.e. those that mimic stages of embryogenesis (reviewed in Gadue et al., 2005; Keller, 2005; Nishikawa et al., 2007).

With the exception of growth plate chondrogenesis, which continues into early adolescence, chondrogenesis is largely completed before birth. Robust chondrogenesis during embryogenesis is a multi-step process involving development of chondrogenic mesenchyme, precartilage condensation of the mesenchyme, the development of chondrocytes, and their maturation into different types. The chondrogenic mesenchymal cells migrate, proliferate and condense through interaction with the adjacent epithelium. In precartilage condensation, cells continue to proliferate and start to differentiate toward chondroblasts, while depositing extracellular matrix containing type II, IX, X and XI collagens and aggrecan. The chondroblasts then proliferate and differentiate into chondrocytes. Finally, growth plate chondrocytes mature into the larger "hypertrophic" chondrocytes that are destined for mineralization. These processes are known to be regulated by hormones and growth factors, such as transforming growth factor (TGF) $\beta$, Wnts, fibroblast growth factors (FGFs), bone morphogenetic proteins (BMPs), insulin-like growth factors (IGFs), sonic/indian hedgehog (Shh/Ihh), and parathyroid hormone-related peptide (PTHrP) (reviewed in Goldring et al., 2006).

Embryonic chondroprogenitors thus have potential as a promising alternative for cartilage cell therapy. Due to the large number of cells required for clinical purposes, embryonic tissues are not a practical source of chondroprogenitors. For humans, progeny derived from human ES cells seem to be the only source of embryonic cells. Major impediments to the clinical use of human ES cell progeny are the risk that contamination of undifferentiated ES cells could lead to teratoma formation in patients, and the limited immunological diversity of available human ES cell lines. The technical and ethical issues involved in producing more such lines have created the need for allogeneic transplantation, which carries the risk of immunological complications. 
There is now a solution to the problem of too few human ES cell lines. In the past couple of years, a nuclear reprogramming technology has been established that enables the induction of ES cell-like pluripotent stem (PS) cells from mouse and human somatic cells (Park et al., 2008; Takahashi \& Yamanaka, 2006; Takahashi et al., 2007; Yu et al., 2007). The technology is based on viral vector-mediated gene transfer into the target somatic cells in culture. Forced expression of pluripotency genes, such as Pou5f1 (Oct3/4), Sox2, Klf4, Nanog and/or Lin28, and the myc oncogene alters the pattern of epigenetic modifications that accumulate on chromatin, to re-establish the transcriptional profile of ES cells, and gives rise to colonies of cells morphologically similar to ES cells. The reprogrammed cells, induced pluripotent stem (iPS) cells, display self-renewal and differentiation capacities equivalent to those of ES cells. Since somatic cells from individual patients can give rise to iPS cells, this technology has opened a practical path toward establishing individualized human PS cells that avoid the immunological problems associated with allografting. Use of the technology also avoids the controversies surrounding the establishment of human ES cells. However, the current iPS technology depends on stable integration of pluripotency gene cDNAs into the chromatin of the recipient, a manipulation that could introduce harmful genetic alterations that in the long term manifest, for example, as tumors, as observed in cases of gene therapy (Nienhuis et al., 2006). In this respect, novel non-integrative methods using a transient-transfection protocol (Okita et al., 2008), EBV-based episomal vector (Yu et al., 2009), an adenoviral vector (Stadtfeld et al., 2008), a Sendai virus vector (Fusaki et al., 2009), small molecules (Shi et al., 2008), or the piggyBac method (Kaji et al., 2009; Woltjen et al., 2009; Yusa et al., 2009) have all been reported. Such methods are likely to lead to the creation in the near future of safer, transgene-free human iPS cell lines suitable for clinical applications.

\section{Chondrogenesis from mouse and human PS cells.}

The ability of ES cells to form cartilage was first seen as cartilage nodule formation in teratomas. Chondrogenic differentiation of mouse and human ES cells has been demonstrated. Here we summarize methods for the initial differentiation of ES cells and the subsequent derivation of chondrocytes.

\subsection{Chondrogenesis in the embryoid body and the outgrowth.}

Embryoid bodies (EBs), the floating cellular aggregates spontaneously generated from PS cells in vitro, allow stem cells to differentiate into a number of cell types derived from each of the three germ layers (endoderm, mesoderm, and ectoderm) in a process that can recapitulate early embryogenesis. As a result, the method of EB formation is widely used for directing ES cell differentiation toward chondrocytic lineages.

For the induction of chondrogenesis, mouse ES cells are differentiated for 5 days in the form of EBs in a serum-containing medium (Fig. 1). EBs are then attached to plastic surface to allows outgrowth of mesenchymal cells, so-called 'outgrowth culture', Fig. 1-1). When outgrowth culture is performed in a chondrogenic medium, some of the mesenchymal cells condense to form cartilage nodules (Kramer et al., 2000). Periodic stimulation of chondrogenic gene expression and electron-microscopic analysis of the nodules (Kramer et al., 2005b) have indicated that the process of in vivo chondrogenesis, from mesenchymal cells through chondroprogenitor cells to mature chondrocytes, and finally to hypertrophic chondrocytes, can be reproduced in culture. However, the efficiency of cartilage nodule formation varies significantly among mouse ES cell lines (Kramer et al., 2005a). 


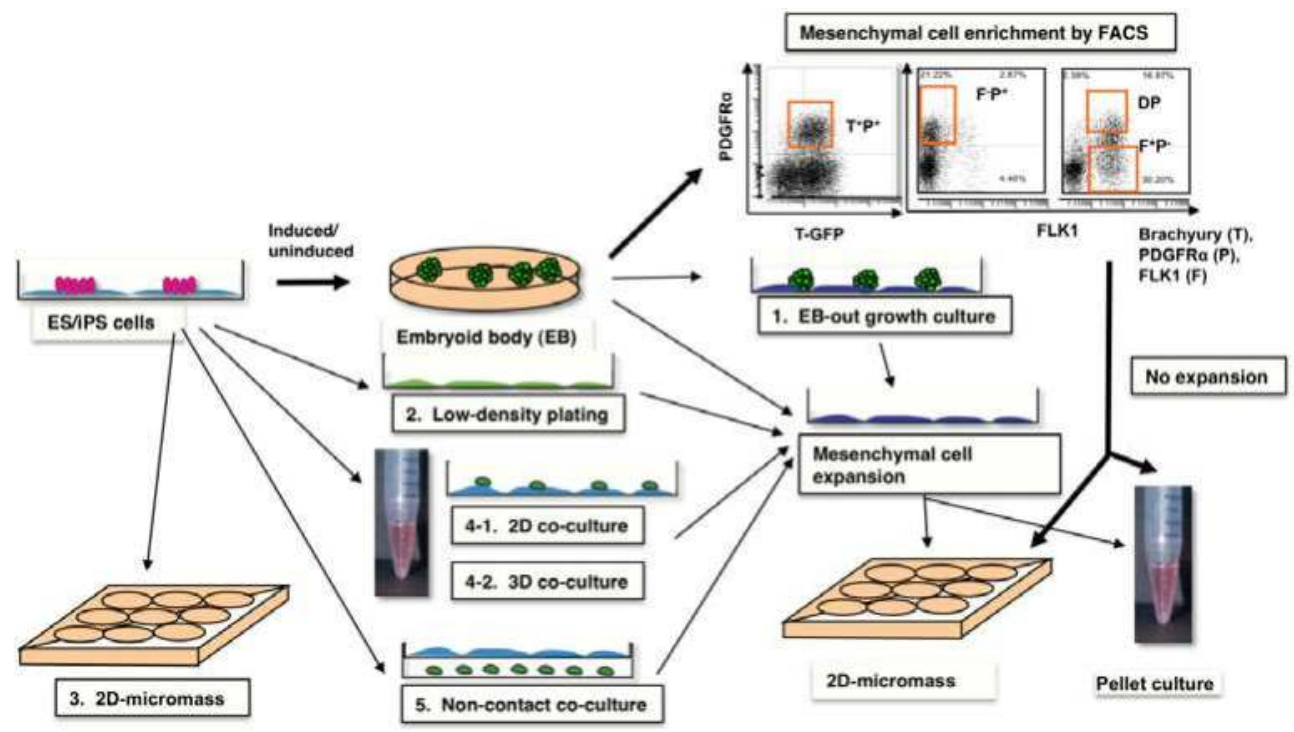

Fig. 1. General strategies for differentiating pluripotent stem cells to chondrocytes

Various growth factors have been tested for their ability to enhance cartilage formation in the outgrowth area. TGF $\beta$-superfamily proteins, such as TGF $\beta$ and BMP, are commonly used to stimulate chondrogenesis from chick embryonic limb mesenchyme (Duprez et al., 1996; Kulyk et al., 1989). According to Kramer's group, addition of BMP2 (2-10 ng/ml) or BMP4 (10 ng/ml) increases, but TGF $\beta 1(2 \mathrm{ng} / \mathrm{ml})$ slightly reduces, the number of cartilaginous nodules (Kramer et al., 2000). Treatment with BMP2 from day 2 to 5 of differentiation (EB formation stage) is sufficient to produce the stimulatory effect. However, these observations differ from ours in three respects. 1) We found that the first 5-day treatment with $2 \mathrm{ng} / \mathrm{ml} \mathrm{BMP} 4$ induced mesoderm, including hemogenic angioblasts, in EBs (Nakayama et al., 2000; Nakayama et al., 2003). 2) Treatment of the isolated mesoderm with BMP4 alone inhibited in vitro chondrogenesis. 3) TGF 33 (10 ng/ml) and BMP4 (10-50 $\mathrm{ng} / \mathrm{ml}$ ), or TGF $\beta 3$ followed by BMP4, synergistically enhanced chondrogenesis (Nakayama et al., 2003). Consistent with our observations, Kawaguchi et al. (2005) have reported that exogenous TGFß3 $(10 \mathrm{ng} / \mathrm{ml})$, but not BMP4 $(100 \mathrm{ng} / \mathrm{ml})$, added from the stage of outgrowth culture, enhances chondrogenesis in the outgrowth, and zur Nieden et al. (2005) have demonstrated that addition of BMP2 $(10 \mathrm{ng} / \mathrm{ml})$ and TGF $\beta 1(2 \mathrm{ng} / \mathrm{ml})$ between days 3 and 5 of differentiation (i.e. EB culture stage) and addition of BMP2 alone during the subsequent outgrowth culture results in pronounced up-regulation of cartilage-specific gene expression.

In contrast, Toh et al. (2007) have demonstrated that mesenchymal cells growing out of human day 5 EBs generated in the absence of the above-mentioned factors form few, if any, cartilage nodules during 21-day outgrowth culture in a serum-containing chondrogenesis medium. However, addition of BMP2 $(100 \mathrm{ng} / \mathrm{ml})$ during the outgrowth culture enhanced cartilage nodule formation (Type II collagen positive) in the outgrowth area, a finding similar to that seen for mouse EB outgrowth culture, although sulfated proteoglycan levels was not changed significantly. 
Thus, differences in timing/duration and magnitude of TGF $\beta$ and BMP signaling lead to different effects of the two factors on chondrogenic differentiation of ES cells.

\subsection{Chondrogenesis from ES cells during 2D-differentiation culture.}

Although the standard differentiation protocol for ES cells involves a 3-dimensional (3D) culture leading to EB formation, ES cells can also differentiate as a monolayer during 2dimensional (2D) culture. The 2D culture method had not been widely used for the generation of mesodermal cell lineages from mouse ES cells, primarily because fewer functional cell types are induced and sustained with this method compared with EB formation culture, especially in an undefined serum-containing medium. However, the advantage of $2 \mathrm{D}$ monolayer differentiation is the ease of visualizing and quantitating intermediate cell types. Dr. Nishikawa et al. (1998) have elegantly demonstrated that differentiation of mouse ES cells on a type IV collagen-coated surface, combined with a serial cell sorting using E-cadherin, platelet derived growth factor receptor- $\alpha$ (PDGFR $\alpha$ ), vascular endothelial growth factor receptor-2 (FLK1/KDR) and vascular endothelial (VE)cadherin markers, not only led to the effective generation of hemogenic angioblasts, but also allowed the determination of the intermediate cell types in the differentiation pathway (Low-density plating, Fig. 1-2). As described below, a similar 2D-differentiation method has been applied to human ES cells to generate MSC-like mesenchymal cells (Barberi et al., 2007; Nakagawa et al., 2009).

While there have been no reports describing application of the 2D monolayer differentiation protocol directly to the development of chondrocytes from human ES cells, one recent publication provided interesting data, though limited, on 2D-micromass culture using chondrogenic medium with BMP2 $(100 \mathrm{ng} / \mathrm{ml})$ added on day 2-3 of culture for the differentiation of human ES cells (Gong et al., 2010) (Fig. 1-3). In contrast to the regular EB formation method (using KSR-medium with no added protein factors), the method resulted in a cell mass that stained strongly with Alcian blue at 14 days. A noteworthy feature of differentiation under the conditions described was its unusual rapidity. The chondrocyte marker gene Sox 9 is already expressed by the time BMP2 is added on day 3 and induces expression of the mesendoderm marker gene Brachyury on day 4. Both transcripts disappear by day 7, when aggrecan and Col2a1 transcripts are maximal. Since Sox 9 is also functionally important for cranial neural crest formation, it was not clear what type of chondrocyte was preferentially produced under the culture conditions.

\subsection{Chondrogenesis from ES cells using co-culture methods.}

Chondrogenesis is controlled by multiple environmental cues, including signals provided through cell-to-cell interaction (e.g. mesenchymal condensation) and secreted morphogenetic factors. Co-culture of ES cells with cells that provide the necessary environmental cues offers an alternative for chondrogenic differentiation of ES cells. 2D differentiation culture of mouse and human ES cells on a layer of supportive cells has been used for the development of lymphohematopoietic cells and endothelial cells (Fig. 1-4-1). One of the earliest and most successful examples is the demonstration of pre-B cell genesis and two-phase (from primitive to definitive) erythropoiesis from mouse ES cells on the op/op mouse bone-derived stromal cell line, OP9 (Nakano et al., 1994, 1996). Since the mid90s, OP9 has become the co-culture partner of choice for developing mesodermal cell types from mouse and human PS cells. As for chondrogenesis, Sui et al. (2003) co-cultured drug- 
resistant mouse ES cells with primary limb bud mesenchymes in 2D micromass culture (Fig. 1-3/1-4-1). After 4 days, the corresponding drug is added to remove progeny from limb bud cells and enrich those from the drug-resistant ES cells. Chondrocytes were detected among the surviving cells. Limb bud mesenchymes proliferate, condense and differentiate into bone and cartilage cells in vivo, and thus are potentially a suitable co-culture partner for chondrogenesis. However, as they are isolated from embryos, mesenchymes are not appropriate for use in humans. Interestingly, the co-culture partner for chondrogenesis can be derived from tissues unrelated to skeleton: e.g. hepatic cells (Lee et al., 2008).

Probably one of the most successful co-culture methods for directing differentiation of human ES cells to chondrocytes is the use of chondrocytes themselves as co-culture partner. Primary human (Vats et al., 2006) or bovine (Hwang et al., 2008a) chondrocytes are placed in a well insert either directly, or after brief expansion, respectively, and human ES cells are 2D cultured underneath for 3-4 weeks in a serum-containing MSC medium in the presence or absence of ascorbate, respectively (Fig. 1-5). The resultant human ES cell progeny express 2.5-3.5 times more type I and type II collagen (the ratio is not changed) and sulfated glycosaminoglycan (sGAG) than those generated without chondrocytes, and form a cartilage-like area in vivo when transplanted encapsulated in a polymer-based scaffold (Vats et al., 2006). Such chondrogenic progeny also grow in the MSC medium, which causes dedifferentiation; however, the cells expanded and dedifferentiated for 3 weeks retain significant chondrogenic activity when subjected to 3D-pellet culture or hydrogel (arginineglycine-aspartate [RDG]-coated polyethyleneglycol [PEG]-based hydrogel, Hwang et al., 2006b) culture in the presence of TGF $\beta 1$ (Hwang et al., 2008a). A 3D coculture of human ES cells with irradiated human chondrocytes in a serum-free chondrogenic medium including TGF $\beta 1$, that resembles the pellet culture for cartilage particle formation, facilitates mesenchymal progeny formation from human ES cells. Such mesenchymal cells form cartilage particles that stain uniformly with Alcian Blue after expansion in a human serumcontaining medium (Fig. 1-4-2) (Bigdeli et al., 2009). Identification of the critical factors produced by the primary chondrocytes may thus provide a route for more efficient chondrogenic differentiation of mouse and human PS cells.

\subsection{Cooperation with tissue-engineering technology.}

Simple implantation of mesenchymal cells in combination with a periosteal patch as in ACI, necessitates additional surgery to isolate periosteum from the patient, and also fails to faithfully reconstitute the architecture of host cartilage within the damaged or diseased area. However, conventional cartilage-formation culture results in a small-size cartilaginous particle that is structurally disorganized and mechanically weak, and therefore is not suitable for clinical-scale cartilage repair. Therefore, attempts have been made to generate large engineered cartilage using artificial or bioartificial scaffold with proper chondroprogenitor cells. In general, the engineered cartilage is a construct consisting of either chondrocytes matured in vitro before implantation, or chondrogenic mesenchymal cells, such as expanded chondrocytes and immature chondroprogenitor cells, which are expected to (re)differentiate or mature in vivo after implantation. In either case, it is intended that the seeded chondroprogenitor cells will survive, grow, differentiate, and reform cartilage structure in the scaffold in vitro and in vivo. Many attempts, especially using biodegradable polymer scaffolds and hydrogel have been described (reviewed in Jukes et al., 2010). Cartilage tissue engineering using MSCs and both types of scaffold has been reported (Fukumoto et al., 2003; Richardson et al., 2006). 
Porous biodegradable polymer scaffolds are based on polylactic acid (PLA), polyglycolic acid (PGA), polyvinyl alcohol (PVA) or polyurethanes. Such solid-type scaffolds are rigid enough to withstand continuous loading, whereas invasive surgical incision is required for implantation. As for application to mouse ES cells, 4 day-old EBs or cells isolated from such EBs (formed in a serum-containing medium) were further cultured on a polyethyleneoxide terephthalate (PEOT)/polybutylene terephthalate (PBT) scaffold in a serum-free chondrogenic medium (Jukes et al., 2008). However, the seeding efficiency of EB cells was extremely low and retention of EBs and seeded EB cells within the scaffold during chondrogenic differentiation was also poor, leading to inefficient, non-homogeneous cartilaginous constructs. In another example, a scaffold made from polycaprolactone (PCL) was used. EBs were formed in a serum-containing medium including retinoic acid, then outgrowth culture was performed in a serum-containing chondrogenic medium, and the outgrowth cells were seeded onto the PCL scaffold (Fecek et al., 2008). Implantation of the resulting constructs yielded a poor result, with only a few chondrocyte clusters inside.

More refined tissue-engineering technology has been used for chondrogenic differentiation from human ES cells. The first report demonstrated that polylactic-co-glycolic acid (PLGA)/PLA scaffold in combination with Matrigel or fibronectin improved the seeding efficiency of human EB-derived cells, leading to cartilaginous area formation in vitro in the presence of TGF $\beta 1$ (Levenberg et al., 2003). Furthermore, a poly-D,L-lactide (PDLLA) scaffold seeded with human ES cells differentiated using the chondrocyte-coculture method and implanted in SCID mice, resulted in areas within the scaffold that expressed type II collagen at 35 days (Vats et al., 2006), although signs of proteoglycan accumulation were weak.

Hydrogels are water-insoluble but highly absorbent materials, and include a variety of gels based on collagen, GAG, agarose, gelatin, alginate, and hyaluronic acid. Hydrogel lacks structural integrity but have the major benefits of supporting the homogeneous distribution of cells at the desired density within the scaffold, and being associated with the less invasive method of transcutaneous injection for implantation. Mouse EB cells encapsulated and cultured in natural hydrogels such as agarose and Matrigel, showed homogenous seeding; however the viability of the seeded cells was very poor and the cells did not form cartilage (Jukes et al., 2008). In contrast, when EBs were directly encapsulated, cells within the EBs had greater viability and chondrogenic differentiation was observed in vitro. Implantation into immunodeficient mice, however, resulted in teratoma formation and a failure to detect cartilage nodules. As found with synthetic hydrogels, Dr. Elisseeff's group has reported that mouse EBs encapsulated in a PEG-based hydrogel formed cartilaginous tissue structures during in vitro culture in the presence of TGF $\beta 1$ (Hwang et al., 2006a). As noted above, they have further modified the PEG-based hydrogels to promote cell adhesion and spreading by the addition of RGD-containing peptides. In the modified gel, MSC-like cells (Hwang et al., 2008b) and chondrogenically committed cells (Hwang et al., 2008a), derived from human ES cells using the EB-outgrowth culture method and the chondrocyte co-culture method, respectively, survived and gave rise to many chondrocytes in vitro. Furthermore, when the MSC-like cells were pre-treated with chondrocyte-conditioned medium, implantation of the PEG-hydrogel construct resulted in cartilage-like tissue formation in damaged articular cartilage by 8 weeks (Hwang et al., 2008b).

In summary, polymer scaffolds and hydrogels work to some extent but are not ideal for promoting generation of cartilage from ES cell-derived mesenchymal cells in vitro or in vivo. 
Although expansion in a chondrocyte-conditioned medium improves the chondrogenicity of the mesenchymal cells, there is considerable scope for improvements to scaffolds to enhance chondrogenesis. In this sense, novel biomaterials, such as hybrid gel/scaffolds (Richardson et al., 2008), nanofibrous scaffold (Hu et al., 2009; Li et al., 2005) and bioartificial matrixes are of great interest.

\subsection{Chondrogenesis enhancement by gene modification}

Directed differentiation of ES cells can be controlled by intracellular proteins such as celltype specific transcription factors. Controlled expression of key differentiation regulators via gene transfer is therefore an alternative strategy for the achievement of lineage-specific differentiation of PS cells: e.g. hepatocytes (Ishizaka et al., 2002) and skeletal muscles (Darabi et al., 2008). The most likely gene candidates for directing chondrogenesis are the high-mobility group (HMG) box protein Sox9 and paired-box-gene Pax1 (Bi et al., 1999; Wallin et al., 1994). Constitutive overexpression of Sox9 or transfection of Sox9, in combination with Sox5 and Sox6, can induce the expression of cartilage marker genes in the absence of specific growth factors or culture conditions (Ikeda et al., 2004; Kim et al., 2005). However, such gene transfer-based facilitation of chondrogenesis is unlikely to be of use in the clinical setting.

\section{Identification of chondroprogenitor cells derived from pluripotent stem cells: undefined mesenchymal cells and MSC-like cells}

Homogenous populations of chondroprogenitor cells are unlikely to be obtained from PS cells solely by directed differentiation culture. However, either for cell transplantation or for engineered cartilage formation before transplantation, purified chondroprogenitor cells are needed, especially because the least contamination with teratoma-forming, undifferentiated ES cells will be harmful. Therefore, a convenient yet effective method for purifying the chondroprogenitors is required. Surface molecules specifically expressed on chondroprogenitor cells have been used to isolate them by fluorescence-activated cell sorting (FACS). We published the first attempt to induce, identify, purify and characterize chondroprogenitors from differentiating mouse ES cells (Nakayama et al., 2003). In particular, the research described focused on 1) the genesis/induction of FLK1-PDGFR $\alpha^{+}$ progeny, which showed a transcriptional profile of lateral plate/extraembryonic mesoderm and posterior paraxial mesoderm, and the FLK1+PDGFR $\alpha^{-}$progeny, which showed lymphohemogenic activity, and the corresponding transcriptome in a serum-free medium, and 2) the control of chondrogenic activity in these fractions of progeny. We demonstrated using 2D and 3D chondrogenesis assays that both mesenchymal progeny have full chondrogenic activity: from mesenchymal condensation to hypertrophic chondrocyte formation. Similarly, Sakurai et al. (2006) demonstrated, as part of their attempt to characterize what they claim to be primitive mesoderm/mesendoderm (FLK1+PDGFR $\alpha^{+}$ progeny), paraxial mesoderm (FLK1-PDGFR $\alpha^{+}$progeny) and lateral plate mesoderm (FLK1+PDGFR $\alpha^{-}$progeny), generated simultaneously from mouse ES cells using Nishikawa's 2D-differentiation method in a serum-containing medium, that the primitive mesoderm and paraxial mesoderm were able to form cartilage nodules during 2D micromass culture. Chondroprogenitor cells from human ES cells have not yet been purified and characterized to the extent of those derived from murine ES cells. 


\subsection{Undefined mesenchymal cells from EBs and EB-outgrowth.}

Chondrogenic activity in human ES cell-derived progeny was first reported by Levenberg et al. (2003) from a study to demonstrate the effect of a 3D polymer scaffold on differentiation of human ES cell progeny. The progeny were EB cells prepared from 8 to 9-day-old EBs formed in KSR-based serum-free medium in the absence of exogenously added protein factors, and used directly without expansion or purification. Toh et al. (2007) have also demonstrated that uncultured, unfractionated EB cells isolated from human day 5 EBs formed in the absence of exogenous protein factors give rise to type II collagen-positive cartilage nodules when subjected to 2D-micromass culture in a serum-containing medium. The effect of BMP2 $(100 \mathrm{ng} / \mathrm{ml})$ added during micromass culture was, however, minimal. Dr. Athanasiou and his colleagues have published a series of reports on chondrogenesis from human ES cells using an EB cell-re-aggregation method (Hoben et al., 2008; Koay et al., 2007; Koay \& Athanasiou, 2008, 2009). ES cells are differentiated as a form of EB for 3 weeks in various media based on a $0-20 \%$ serum-containing chondrogenic medium with or without the addition of combinations of growth factors such as TGF $\beta$, PDGF, IGF, sonic hedgehog and/or BMP2/4/6. EBs are then disrupted, and the cells are resuspended without expansion or purification at a high density in a small volume (e.g. $20 \mu \mathrm{l}$ ) of $0-1 \%$ serumcontaining chondrogenic medium with or without TGF $\beta 1$ or IGF1, and transferred into a 3 $\mathrm{mm}, 2 \%$ agarose well. Although a macroscopic particle forms in 4 weeks, there is only a weak indication that cartilage particles form, as assessed by the production of ECM rich in type II collagen and GAG. Interestingly, TGF $\beta+B M P 2 / 4$ treatment during EB culture in the serum-containing chondrogenic medium is most effective at stimulating the accumulation of GAG and type VI collagen in 3 weeks, whereas EB culture in an agarose-coated Transwell, conditions under which chondrocytes are co-cultured as a monolayer, strongly stimulates the accumulation of type II collagen within EBs (Hoben et al., 2009). In summary, crude EB cells without expansion or sub-fractionation failed to show robust chondrogenic activity in any of the in vitro culture methods used. The addition of protein factors at various steps of differentiation had no dramatic effect.

Attempts have also been made to generate morphologically uniform mesenchymal progeny from crude EB cells, before assaying chondrogenesis. Human ES cells are differentiated in the form of EB for 4 to 10 days in the absence of exogenous protein factors in a serumcontaining medium (Toh et al., 2009; Xu et al., 2004), or the standard KSR-based serum-free medium (Hwang et al., 2006b; Hwang et al., 2008b; Terraciano et al., 2007). The resultant EBs are either attached to a plate and cultured in the corresponding factor-free EB medium to allow the outgrowth of mesenchymal cells (Fig. 1-1), or subjected to 2D micromass culture, from which mesenchymal cells are isolated (Toh et al., 2009). Multiple passaging of the outgrowth cells in the serum-containing MSC medium results in a morphologically homogeneous mesenchymal cell population (Fig. 1-6). However, such cells are not chondrogenic in standard 3D pellet culture in the presence of TGF $\beta$. Weak chondrogenic activity was detected only when the cells were encapsulated in a special scaffold (e.g. RDGPEG hydrogel) and stimulated by periodic pressures (Terraciano et al., 2007). Interestingly, expansion of the mesenchymal cells from 2D micromass culture in the presence of growth factors to some extent preserved the ability of the cells to accumulate Alcian blue-positive matrix in the following 3D pellet assay (Toh et al., 2009). The significant level of type I collagen in the resulting particles suggested the formation of fibrocartilage.

As described above, chondrocyte-coculture during EB formation improved the "expansion" strategy for obtaining morphologically uniform chondroprogenitors. For example, human 
ES cell differentiation with irradiated chondrocytes using the 3D pellet culture-like method in a serum-free chondrogenic medium with TGF $\beta 1$ resulted at day 14 in a mixture of cells that included chondrocytes. Although the chondrocytes bore similarities to co-cultured irradiated chondrocytes, their expansion in a human serum-containing medium led to the accumulation of mesenchymal cells with the capacity to reform a cartilage pellet that stained uniformly with Alcian Blue (Bigdeli et al., 2009). While such cells were not adipogenic and only weakly osteogenic, the chondrocyte co-culture method is suitable for specifying chondroprogenitor cells from human ES cells.

\subsection{ES cell-derived MSC-like cells.}

MSCs are in vitro-defined chondroprogenitor cells present in various adult tissues. Therefore, ES cell-derived chondroprogenitor cells may possess MSC-like properties. The first demonstration of the genesis of MSC-like cells from human ES cells was that of Barberi et al. (2005), who used a 2D co-culture method for differentiation. A long-term (40 day) human ES cell differentiation on the OP9 stromal cell line in a serum-containing medium was followed by $\mathrm{CD}^{+} 3^{+}$cell isolation and further culture in a serum-containing MSC medium without OP9. The method was later modified to include a stroma-free 2D differentiation culture, in which human ES cells are cultured at low cell density on a gelatincoated plate in serum-free medium without protein factors for 20 days (Barberi et al., 2007) to produces mesenchymal cells. $\mathrm{CD}^{+} 3^{+}$cells emerged at 14 days of expansion of the mesenchymal cells in serum-containing MSC medium. The $\mathrm{CD}^{+}{ }^{+}$cells, sorted then maintained in the same medium, showed bone-cartilage-fat "tri-lineage" potential. Nakagawa et al. (2009) used a similar method to produce mesenchymal cells with in vitro trilineage potential. They plated human ES cells directly onto gelatin-coated plates and maintained them in serum-containing medium in the presence of FGF2. Interestingly, however, unlike other studies, TGF $\beta$ did not stimulate the accumulation of GAG and type II collagen during 3D-pellet chondrogenesis culture.

The expanded EB-outgrowth cells in serum-containing MSC medium were osteogenic and adipogenic, but poorly chondrogenic (Hwang et al., 2008b), and lacked the expression of the MSC marker CD73 (Hwang et al., 2006b). Interestingly, expansion of the outgrowth cells in a chondrocyte-conditioned medium significantly increased the chondrogenic ability of the cells and was associated with a better outcome after transplantation of the cells into a critical size cartilage defect in the femoropatellar groove of nude rats. Probably the most extensive analysis of MSC-genesis through EB-outgrowth cells was the report by Mahmood et al. (2010), which describes the differentiation of human ES cells in the absence of exogenous protein factors, but the presence of a high concentration $(10 \mu \mathrm{M})$ of the small molecule inhibitor of Nodal/Activin/TGF $\beta$ receptor (ALK7/4/5) kinase, SB431542, for 10 days in a KSR-based serum-free medium. Although SB431542 is inhibitory for mesoderm specification, even at a lower concentration (Gadue et al., 2006), and induces neuronal differentiation (Smith et al., 2008) from mouse and human ES cells, transcripts representing myogenic cells (as well as neural cells) were induced at day 10. EB-outgrowth culture and subsequent maintenance culture for the mesenchymal cells was performed in a chemically defined serum-free medium in the presence of $1 \mu \mathrm{M}$ SB431542. Cells expressing myocytic and neuronal proteins persisted after cell expansion. To generate CD73+ MSCs, such cell populations must be cultured in a serum-containing medium for 20 days, during which signs of myocytes and neuronal cells disappear. The chondrogenic activity of the MSC-like cells developed by this method was demonstrated in vivo by studies in nude mice. 
Overall, the chondrogenic activity of the human ES cell progeny reported thus far is weak, and not highly susceptible to enhancement by the protein factors tested. Interestingly, for the genesis of MSC, expansion culture of the progeny in a serum-containing MSC medium appears to be essential. Therefore, the chondrogenic activity as part of the MSC activity can be generated/enhanced during such culture. However, expansion culture of human ES cell progeny does not always accumulate MSC-like chondroprogenitor cells, possibly reflecting the low yield of MSCs within the progeny population. It is worth noting that, again, chondrocyte-coculture, either during EB formation or during the expansion culture phase, improved the chondrogenic activity of the human ES cell progeny, even after expansion.

\section{Lineage-specific chondroprogenitors from pluripotent stem cells}

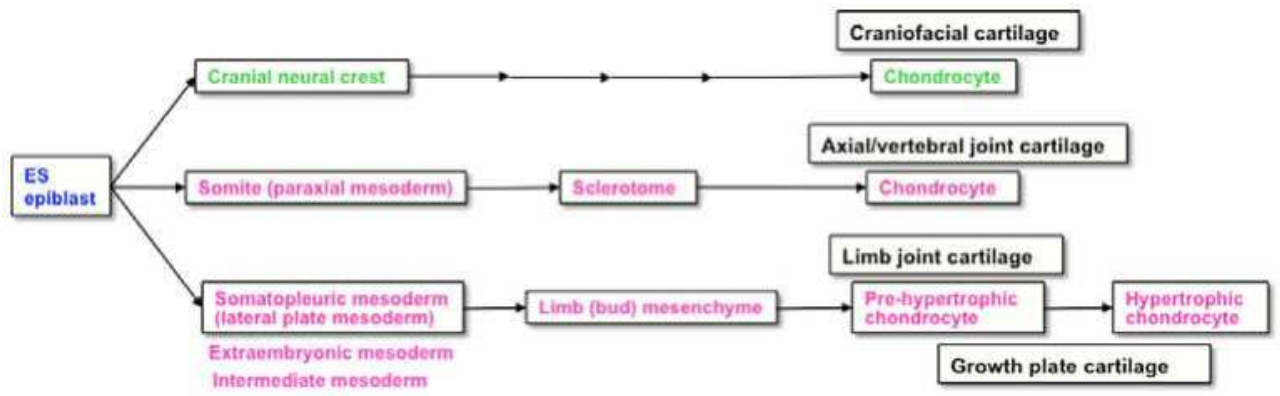

Fig. 2. Key developmental intermediates from pluripotent stem cells to chondrocytes

Embryonic chondrocytes are responsible for the robust chondrogenesis that occurs during embryogenesis. The three sources of embryonic chondrocytes and their precursor cells (chondrogenic mesenchymes and chondroprogenitors) are lateral plate mesoderm for limb joint and growth plate chondrocytes, paraxial mesoderm for vertebral and rib chondrocytes, and cranial neural crest for craniofacial chondrocytes (Fig. 2). The mesodermal chondrocytes give rise to hyaline cartilage at joint surfaces and fibrocartilage in the patella, meniscus, and vertebral disk. In contrast, cranial neural crest-derived chondrocytes make craniofacial cartilage that is mostly fibrocartilage or elastic cartilage. Therefore, embryonic chondrocytes from lateral plate mesoderm, paraxial mesoderm or cranial neural crest might preferentially generate different types of cartilage in a given environment. Recent observations that bone marrow MSCs arise from the neural crest in young mice (Morikawa et al., 2009; Takashima et al., 2007) suggest that the chondrogenic potential of adult MSCs and mesodermal chondroprogenitor cells might also be different.

In vitro differentiation of mouse and human ES/iPS cells is thought to represent the early stages of embryogenesis. In fact, progeny displaying characteristics of a particular germlayer can be induced in an exogenous protein factor-dependent manner from mouse ES (reviewed in Gadue et al., 2005; Keller, 2005; Nishikawa et al., 2007). The factors used are developmental factors, defined by genetic and embryological studies, which provide essential signaling between pluripotent cells (inner cell mass and epiblast) and the differentiated cell type of interest. However, to date, only a small number of reports describe such a "factor biology" approach to the generation of chondrocytes with distinct germ-layer specificity (Kawaguchi et al., 2005; Nakayama et al., 2003; Sakurai et al., 2006; Tanaka et al., 2009), and these have all dealt with mouse ES cells. There have been no reports of controlled 
differentiation of human ES/iPS cells to lineage-specific chondrogenic progeny. A few reports have addressed the effects of TGF 31 , BMP2, and Activin (or its inhibitor SB431542) on human ES cell differentiation. Although the origin of the developed chondroprogenitors has not been explored, the expression of mesodermal genes in the progenitor population after extensive expansion has been reported (Harkness et al., 2009).

\section{Mesodermal chondroprogenitors: differential specification and prospective isolation from differentiating pluripotent stem cells}

Applying the "factor biology" strategy, progeny displaying characteristics of different types of mesoderm are induced from mouse ES cells in a defined medium (Gadue et al., 2006; Nostro et al., 2008; Tanaka et al., 2009). A similar principle has been applied to human ES/iPS cells to develop various mesodermal cell types (reviewed in Murry \& Keller, 2008; Nishikawa et al., 2008). Mesoderm is developed through gastrulation in vivo, a time when posterior primitive ectoderm (or epiblast) undergoes epithelial-to-mesenchymal transition to give rise to extraembryonic mesoderm, cardiac and lateral plate mesoderm, and subsequently to paraxial mesoderm and axial mesendoderm. The TGF $\beta$-superfamily (TGF $\beta$, Nodal/Activin, and BMP), Wnt, and FGF are involved in these processes, and are effective in different doses and combinations in determining the differential specification of mesodermal cells from ES cells (reviewed in Gadue et al., 2005; Keller, 2005; Nishikawa et al., 2007). For transplantation in the clinic, it will be necessary to purify the generated mesodermal chondroprogenitor cells from unwanted contaminants. FLK1/KDR and PDGFR $\alpha$ are useful surface markers with which to monitor the early stages of mesoderm development in the mouse. Flk1 expression is detected in extraembryonic and lateral plate mesoderm (Yamaguchi et al., 1993), which gives rise to somatopleuric mesoderm, the origin of limb bud chondrogenic mesenchymal cells. In contrast, Pdgfra expression is detected in most early mesodermal cells, but surface expression of PDGFR $\alpha$ is restricted in paraxial mesoderm derivatives (Takakura et al., 1997). Dr. Nishikawa and his colleagues (1998) have started using these markers for the identification and isolation by FACS of mesodermal progeny from mouse ES cells. Our group has combined factor biology and FACS purification to selectively generate, isolate and characterize chondroprogenitors derived from mouse and human PS cells.

\subsection{Signaling code for differential specification of ES cell progeny.}

In applying the combined factor biology/FACS purification approach, mouse ES cells are differentiated in a serum-free medium and the resulting EBs are harvested at an appropriate time. Single-cell preparations from EBs are immunostained for FACS using antibodies to Ecadherin (E), N-cadherin (N), PDGFR $\alpha(P)$, and FLK1 (F). The E- EB cells, free of undifferentiated ES cells and endoderm, are further fractionated with $\mathrm{N}, \mathrm{F}$ and $\mathrm{P}$, and subjected to bioassays and in vivo assays. Brachyury $(\mathrm{T})^{+}$mesendodermal/early mesodermal progeny are generated in 3 days in the presence of exogenous WNT3a and endogenous Nodal-like activity. Although exogenous BMP4 induces T, it does so through induction of endogenous WNT and Nodal-like activities (Tanaka et al., 2009). The $\mathrm{P}^{+}$progeny, the first sign of mesenchymal cell genesis, become obvious by day 4 . When Activin A is provided exogenously with WNT3a or BMP4, $\mathrm{F}^{+}$cells start to accumulate, as was also reported by the Keller group (Fehling et al., 2003). Approximately $90 \%$ of the $\mathrm{F}^{+}$and/or $\mathrm{P}^{+} \mathrm{EB}$ cells developed by day 5 are derived from $\mathrm{T}^{+}$progeny and are also $\mathrm{N}^{+}$, implying that the cells include mesodermal derivatives (Fig. 3). 


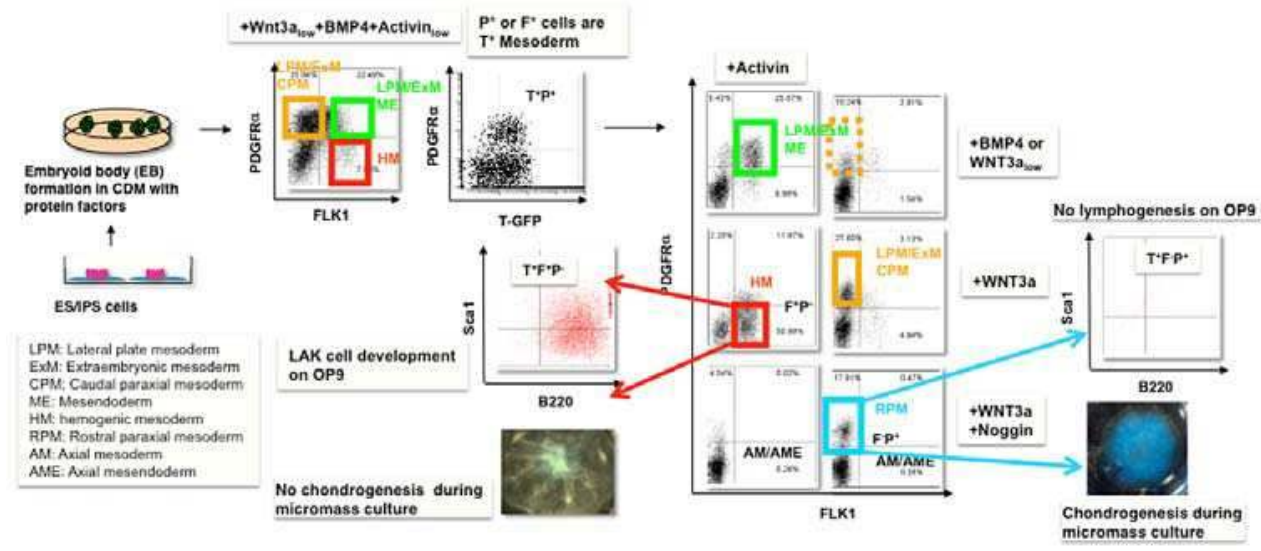

Fig. 3. Chondrogenic paraxial mesoderm from mouse pluripotent stem cells

Global transcriptional profiling has shown that the expression of genes associated with pluripotent stem cells (Oct3/4/Pou5f1 and Nanog) and epiblasts (Fgf5) is confined to the TN-F-P- fraction (which is mostly $\mathrm{E}^{+}$). Markers for rostral paraxial mesoderm such as Tcf15/Paraxis, Uncx, Meox1, Tbx18 and Mesp2, are confined to the $\mathrm{T}^{+} \mathrm{N}^{+} \mathrm{F}-\mathrm{P}^{+}$cells generated when WNT signaling is activated and BMP signaling is inactivated. In contrast, Foxf1 and Hand2, expressed in lateral plate and extraembryonic mesoderm, are detected mostly in the same $\mathrm{T}^{+} \mathrm{N}^{+} \mathrm{F}-\mathrm{P}^{+}$cell fraction, but generated only under active WNT and BMP signaling. The genes associated with hemogenic mesoderm/endothelium, such as Scl/Tal1, Hhex, Ikaros, Chd5, Tie2/Tek and Cd34, are exclusively expressed in the $\mathrm{T}^{+} \mathrm{N}^{+} \mathrm{F}^{+} \mathrm{P}-$ fraction generated efficiently when WNT, BMP and Nodal/Activin signaling are activated via exogenous factors (Tanaka et al., 2009).

Consistent with the notion that BMP signaling is inhibitory to ES cell-derived neurogenesis, and that head induction depends on both BMP/Nodal-inhibition and WNT inhibition in vivo, T-N+F-P- neural precursors, expressing early neural markers such as Sox1, Nestin, Pax6, Neurod and Neurog, are differentiated from ES cells when none of the three signaling mechanisms is activated (Fig. 5). Interestingly though, when BMP signaling was activated in the presence of WNT inhibitors, non-mesodermal T-NdimF-P+ mesenchymal cells were generated at low levels, as discussed in detail below.

Lateral plate/extraembryonic mesoderm specification from mouse ES cells, as judged by gene expression profiling, is achieved by exogenous BMP4 or WNT3a, although both WNT and BMP signaling are activated under either condition. In contrast, rostral paraxial mesoderm specification requires BMP inhibition when an optimized level of WNT3a is provided. These results imply that activation of either BMP or WNT signaling results in the activation of the other during ES cell differentiation. In support of this idea, exogenous BMP4 upregulated the levels of Wnt mRNAs (Wnt5a, Wnt4 and, weakly, Wnt2, Wnt5b and Wnt11) and suppressed the level of the Wnt inhibitor gene (Sfrp1 and Sfrp2) mRNAs. On the other hand, exogenous WNT3a elevated expression of Bmp and Nodal transcripts.

\subsection{Prospective isolation of mesodermal chondroprogenitors from mouse ES cells.}

We were the first to report the use of the cell surface markers FLK1 (F) and PDGFR $\alpha(P)$ to enrich by FACS a population of mesenchymal progeny that demonstrated chondrogenic 
activity in vitro from a crude mixture of differentiated ES cells (Nakayama et al., 2003). The conditions for ES cells differentiation produced lateral plate mesoderm and extraembryonic mesoderm, but no rostral paraxial mesoderm (WNT3a[or BMP4] \pm Activin A, Fig. 3). The isolated $\mathrm{F}^{-} \mathrm{P}^{+}$progeny contained lateral plate/extraembryonic mesoderm and posterior paraxial mesoderm. The $\mathrm{F}^{+} \mathrm{P}-$ progeny contained hemoangiogenic (lateral plate/extraembryonic) mesoderm. Both cell fractions reproducibly showed chondrogenic activity in vitro. Rostral paraxial mesoderm transforms itself into somite, an epithelial structure that later gives rise to progenitors for skeletomyogenesis and axial skeletogenesis. We have also recently reported that under conditions in which no lateral plate/extraembryonic mesoderm is specified but rostral paraxial mesoderm is selectively induced from ES cells (WNT3a+Noggin, Fig. 3), the F-P+ progeny represents the rostral paraxial mesoderm and is also rich in chondroprogenitors (Tanaka et al., 2009). Unfortunately, F- $\mathrm{P}^{+}$is not a characteristic of either type of chondrogenic mesoderm. The availability of a reporter cell line using a mesoderm type-specific transcription factor gene (e.g. Meox1) would be a useful tool for studying the cellular developmental pathway and further purification. However, considering future clinical application, cell surface markers specific for each mesoderm-type and the chondroprogenitors will be needed.

\subsection{Prospective isolation of mesodermal chondroprogenitors from human ES cells.}

The prospective isolation of lineage-specific chondroprogenitor cells from human PS cells using specific cell surface markers without extensive expansion has not been reported. However, an interesting report published recently describes how the delta-like $1 /$ fetal antigen 1 (dlk1/FA1), a transmembrane protein belonging to the Notch/Delta/Serrate family, is useful in some cases (Harkness et al., 2009). We reported a serum-free differentiation method for human ES and iPS cells that favors the generation of hematopoietic progenitor cells in an exogenous WNT3a-dependent manner (Wang \& Nakayama, 2009; Wang et al., 2010) (Fig. 4, right panel), which we have now adapted to promote paraxial mesoderm formation. Specification of paraxial mesoderm from human ES and iPS cells was achieved using conditions similar to those described for mouse ES cells. In addition, FACS-purified human paraxial mesoderm was found to have chondrogenic activity when measured by the conventional 2D micromass and 3D pellet chondrogenesis assays (under the same condition

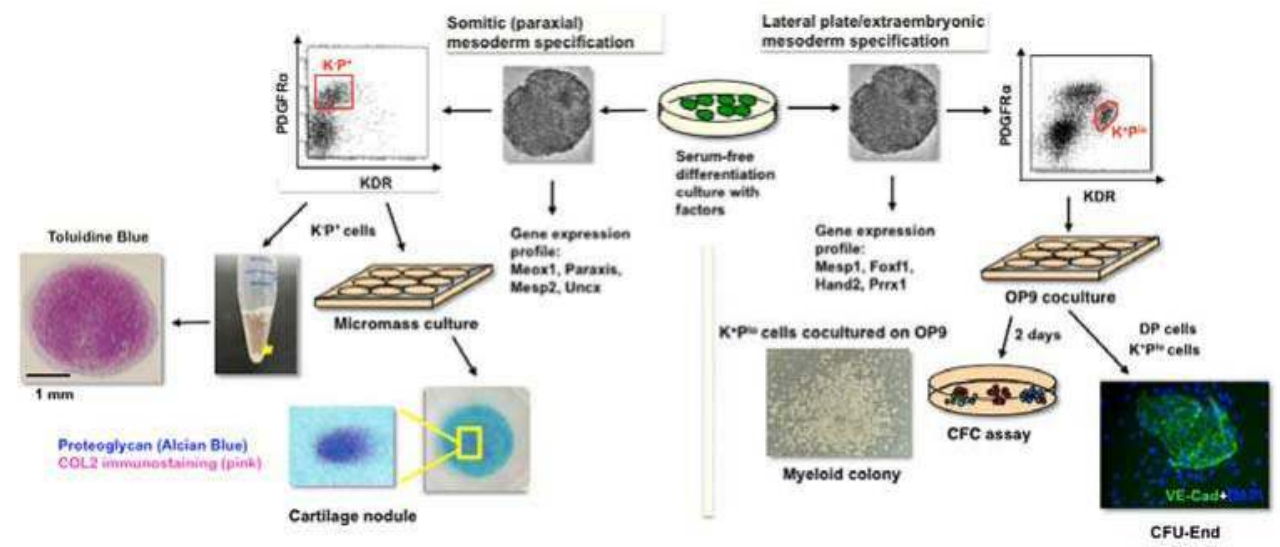

Fig. 4. Chondrogenic paraxial mesoderm from human pluripotent stem cells 
established for the mouse ES cell-derived rostral paraxial mesoderm) (Umeda, et al. unpublished observations; Fig. 4, left panel). Chondrogenic activity of the isolated paraxial mesoderm is robust, so that RDG-hydrogel or another scaffold is not necessary for in vitro assays.

\section{Directed specification of MSC-like chondroprogenitors from pluripotent stem cells: neural or potentially other non-mesodermal lineages}

Cranial neural crest cells arise from the forebrain (to form the frontonasal skeleton), the midbrain (to form the facial bone and cartilage and jaw bone) and the hindbrain (to form the middle ear and neck bones), in distinct populations. They differ from trunk neural crest in their potential to differentiate into cartilage, bone and connective tissues even in vitro (Abzhanov et al., 2003). Cranial neural crest cells are mesenchymal cells, generated from the neuroepithelium/surface ectoderm border of the fore-, mid- and hindbrain via epithelial-tomesenchymal transition. They migrate anteriorly or ventrally to colonize distinct regions (the frontonasal process or pharyngeal arch 1 to 3 ) and form region-specific skeletal elements. Wnt, BMP, FGF, and Notch pathways are involved in neural crest cell specification, although the timing and order of the signals required is not fully understood (Steventon et al., 2005).

\subsection{MSC-like cells from mouse ES cell: non-mesodermal origin.}

Neural crest derivatives such as peripheral nerve cells were first generated from mouse ES cells using undefined stromal cell-derived activity (which is thought to contain Nodalinhibitor and WNT-inhibitor) to induce neural commitment, followed by BMP4 treatment

(Mizuseki et al., 2003). In contrast, while a brief treatment with retinoic acid during EB culture in a serum-containing medium failed to induce T, MSC-like tri-lineage potential cells developed during the subsequent EB-outgrowth culture. A sign of neural crest cell formation was also detected (Kawaguchi et al., 2005), consistent with the finding from

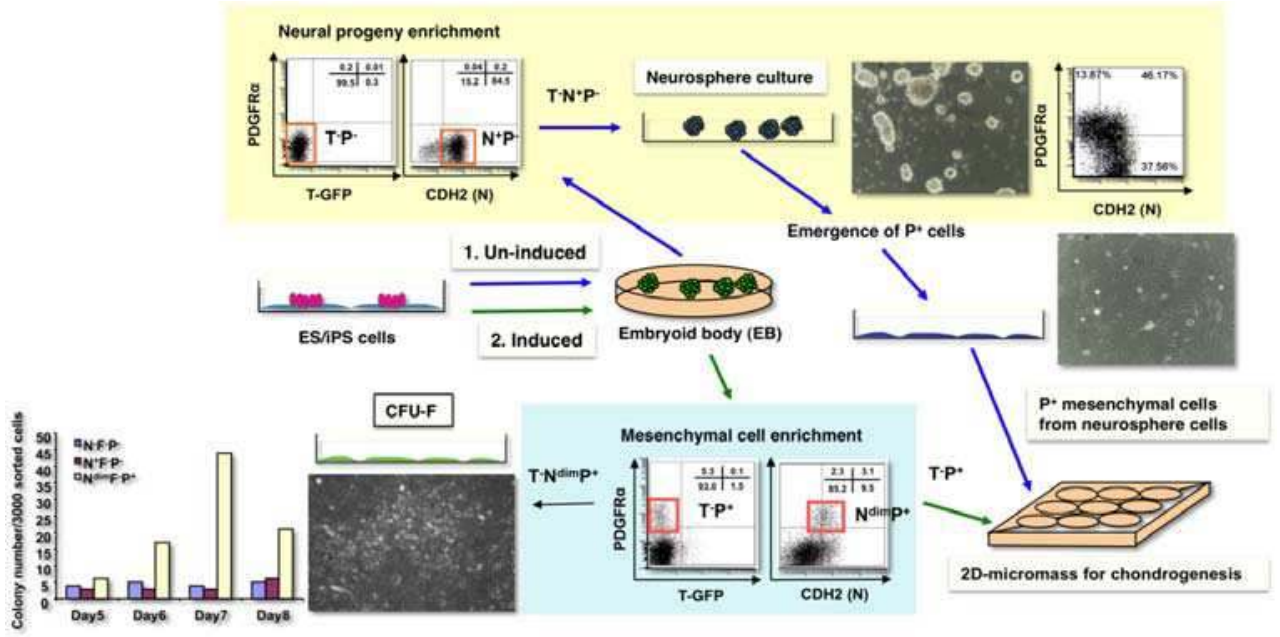

Fig. 5. Non-mesodermal chondroprogenitor from mouse pluripotent stem cells 
lineage-tracing analysis that MSCs arise from the neural crest during mouse embryonic development (Morikawa et al., 2009; Takashima et al., 2007). We have also produced nonmesodermal (as judged by the lack of $\mathrm{T}$ expression) mesenchymal cells, i.e. T-NdimF- $\mathrm{P}^{+}$cells (hereafter called T-P+ cells) from the isolated T-N+F-P- neural progeny (hereafter called T-Pcells) that are generated from mouse ES cells without retinoic acid or any particular protein factors (Fig. 5, Un-induced). When the isolated T-P- cells were subjected to neurosphere culture in the neural crest stem cell culture medium (Wong et al., 2006), T- $\mathrm{P}^{+}$cells emerged in 4 days. MSC-like spindle-shaped mesenchymal cells, which are strongly chondrogenic in 2D micromass culture (data not shown), can be generated from such $\mathrm{T}^{-} \mathrm{P}^{+}$cells after brief expansion in serum-containing MSC medium. These mesenchymal cells are probably of neural origin but their relevance to neural crest has not been established.

Direct differentiation of mouse ES cells to similar non-mesodermal T- $\mathrm{P}^{+}$mesenchymal cells has also been achieved by the addition of BMP4 or WNT3a from day 0 of differentiation in a serum-free medium (Fig. 5, Induced). The T-P+ cell population appearing from day 4 of differentiation is enriched in chondrogenic activity that is detectable from day 6 . In addition, CFU-F activity also emerges from day 6, and is confined in the T- $\mathrm{P}^{+}$fraction. The mesenchymal/fibroblastic cells derived from the resulting colonies spontaneously gave rise to Oil Red $\mathrm{O}^{+}$adipocytes on reaching confluence (data not shown). Mineral deposition was readily detected within 20 days of culture in osteogenic medium (data not shown). Thus, the chondrogenic $\mathrm{T}^{-} \mathrm{P}^{+}$progeny possess adult MSC-like (tri-lineage potential plus CFU-F) activity, although the lineage relationship of this population of cells with neural crest has not been demonstrated.

\subsection{Non-mesodermal MSC-like cells from human ES cells.}

Mesenchymal cells with MSC-like phenotypes can also be isolated during directed neural crest cell differentiation from human PS cells (Lee et al., 2007; Mahmood et al., 2010; Zhou \& Snead, 2008). Although a morphologically homogenous cell population can be obtained simply by subsequent passaging (Bigdeli et al., 2009; Hwang et al., 2006b; Mahmood et al., 2010), purification of particular mesenchymal cells by mechanical dissection based on morphological criteria (Hwang et al., 2008a) or by FACS using MSC-specific cell surface markers (Barberi et al., 2005; Lee et al., 2007) helps to enrich functional MSC-like cells and demonstrate their multi-lineage differentiation into fat, cartilage, bone, and muscle cells. The development of MSCs often requires long-term culture (sometimes for more than 2 months) in a serum-containing medium. A challenge for the future will be to determine how extensive expansion culture is associated with the genesis of MSCs from ES cell progeny.

\section{Optimization of the factor environment for chondrogenesis from PS cell- derived chondroprogenitor cells}

The 2D micromass or 3D pellet cultures, in which cells are maintained at a very high density, can mimic precartilage condensation as observed during the early stage of chondrogenesis. Both culture systems have been extensively used to differentiate embryonic limb mesenchymal cells into chondrocytes, and to induce chondrogenic differentiation of mesenchymal cell lines (Denker et al., 1995) and MSCs (Johnstone et al., 1998; Mackay et al., 1998; Yoo et al., 1998). Therefore, these assays have been used for verifying chondrogenic activity of the ES cell progeny. Cartilaginous particles formed by the $3 \mathrm{D}$ pellet culture allow 
histological and immunohistochemical analyses, which in turn provide semi-quantitative information on the type of cartilage formed. Chondrogenesis does not occur spontaneously, particularly in a serum-free environment, but must be stimulated by the addition of protein factors. According to the reports, factors thus far tested for crude, expanded or purified ES cell progeny are largely resemble those used for chondrogenic induction from human MSCs, namely TGF $\beta$, BMP2/4, BMP6/7. However, many other signalling molecules are known to be essential for chondrogenesis (Fig. 6A). There is a possibility that such non-TGF $\beta$-BMP signaling mechanisms may functionally distinguish the chondroprogenitor cells of different origin, which would support the hypothesis that the different lineage-specific chondroprogenitor cells would behave differently in a given environment in vivo.
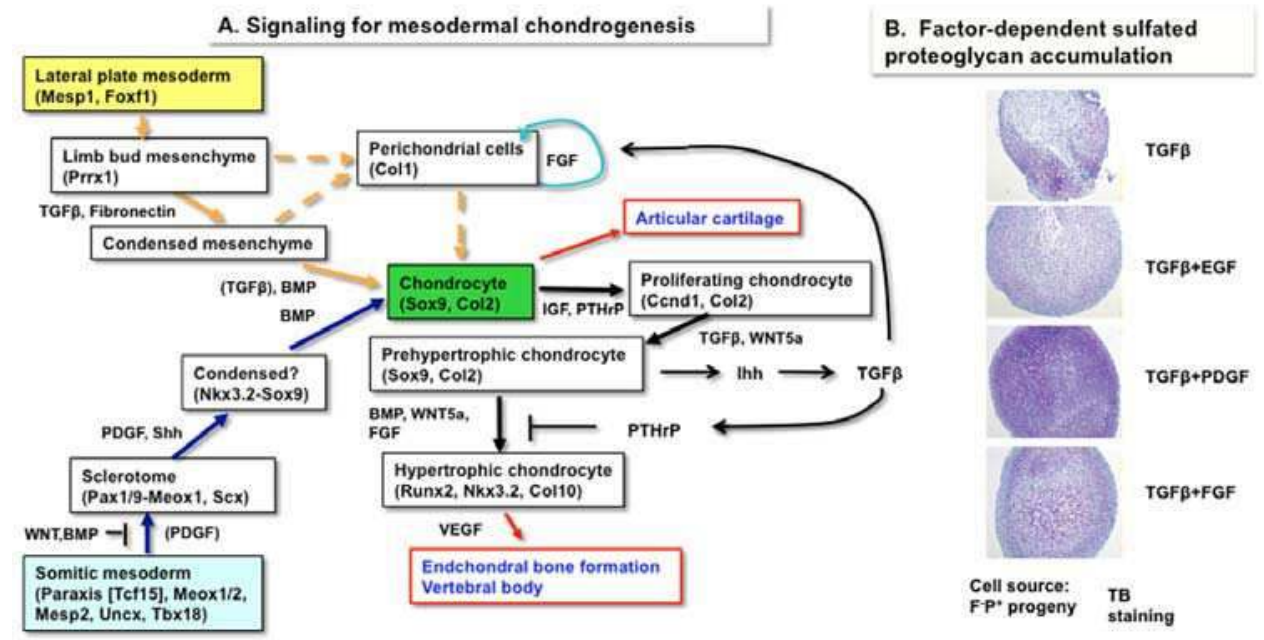

Fig. 6. Growth factor signaling requirement for mesodermal chondrogenesis in vivo and in vitro

To demonstrate that the mesodermal progeny generated from mouse ES cells are capable of forming a macroscopic cartilage particle dependent on added protein factors, we employed the 3D pellet assay method based on a chemically-defined serum-free medium, originally established for adult MSCs (Johnstone et al., 1998; Mackay et al., 1998; Yoo et al., 1998), and developed a 2D micromass culture method using the same serum-free medium (Nakayama et al., 2003). Combined with the serum-free EB formation method (Johansson \& Wiles, 1995; Nakayama et al., 2000; Wiles \& Johansson, 1997), we have established an entirely serum-free culture system that supports differentiation from ES cells to mesodermal progeny, and on to mesodermal chondrocytes (Nakayama et al., 2003; Tanaka et al., 2009). The resulting ES cellderived mesodermal progeny has proven sensitive to environmental cues such as PDGF, TGF $\beta$ and BMP4 in the serum-free pellet culture and responds to them by producing different types of cartilage particle: e.g. proteoglycan-rich, type I collagen-poor hyaline-like cartilage, or proteoglycan-poor, type I collagen-containing fibrocartilage (Nakayama et al., 2003). TGF $\beta$ alone facilitates stable particle formation but cartilage matrix deposition is weak, whereas TGF $\beta+$ PDGF allows uniform deposition of cartilage matrix in the particle (Fig. 6B). TGF $\beta+$ epidermal growth factor (EGF) forms a large particle consisting mainly of 
undifferentiated mesenchymal cells that do not deposit cartilage matrix. TGF $\beta+F G F$ results in a large particle comprising a thick perichondrial cell layer on the surface and hypertrophic-like chondrocytes inside, which is associated with weak deposition of cartilage matrix.

\section{Future perspective}

Since first reported by Kremer, et al. in 2000, research on chondrogenesis from PS cells has made rapid progress. The question of whether ES cell-derived chondroprogenitor cells are MSCs has been addressed primarily with human ES cells. A consistent observation in all reported methods is that the genesis of MSCs from ES cells requires expansion of precursor (mesenchymal) cells for various times in a serum-containing MSC medium. What is the critical role of serum in the process? Furthermore, another interesting question relates to the identity of chondrocyte-derived secreted signals that best support the genesis and maintenance of the chondroprogenitor and MSC activities from human ES cells. Defining both signaling components and mechanisms will shed light on the fundamental biological mechanism of the genesis of MSC activity in vivo. On the other hand, lineage origin of the developed chondrocytes or their precursor (mesenchymal) cells has never been addressed. There are, however, good reasons to hypothesize that the ES/iPS cell-derived embryonic chondrocytes differ from adult MSCs in their ability to regenerate hyaline cartilage, and ES/iPS cell-derived embryonic chondrocytes also differ, depending on their lineage origin, in their efficiency and preference for forming particular types of cartilage. To address these suggestions, greater control of the differentiation of PS cells is needed to allow production of sufficient lineage-specific chondroprogenitors for comparative preclinical (or clinical) studies with adult MSCs. For example, methods need to be established for facilitating maturation of rostral paraxial mesoderm to Pax1-positive sclerotome, producing Prrx1expressing limb mesenchyme from lateral plate mesoderm, and improving differentiation and isolation methods for cranial neural crest and their osteochondrogenic progeny from human PS cells. In addition, finding the critical environmental cue or cues that direct the type of cartilage formed from human PS cell-derived chondrocytes of a particular developmental origin will help to generate that type of cartilage in vitro (in scaffold) and in vivo. Such investigations will facilitate the establishment of a new cell-based therapy for the treatment of cartilage defects. In this context, it is worth noting that a human ES cell-derived fibrocartilagenous particle transplanted to a size-matched osteochondral defect in rat knee showed multi-step changes in the matrix and type of component cells (Toh et al., 2010). In addition during preparation of this review, one new paper reporting that mesodermal differentiation of human ES cells in a 2D culture using altered growth factor treatments in a chemically defined medium: i.e. WNT3a and Activin A, then BMP4 and FGF2, and then BMP4 is replaced gradually with GDF5, which resulted in Sox9 and type II collagen expressing chondrocytes, was published (Oldershaw et al., 2010).

\section{References}

Abzhanov, A.; Tzahor, E.; Lassar, A.B. \& Tabin, C.J. (2003). Dissimilar regulation of cell differentiation in mesencephalic (cranial) and sacral (trunk) neural crest cells in vitro. Development, Vol. 130, No. 19, 4567-4579. 0950-1991 
Asakura, A.; Komaki, M. \& Rudnicki, M. (2001). Muscle satellite cells are multipotential stem cells that exhibit myogenic, osteogenic, and adipogenic differentiation. Differentiation, Vol. 68, No. 4-5, 245-253. 0301-4681

Barberi, T.; Willis, L.M.; Socci, N.D. \& Studer, L. (2005). Derivation of multipotent mesenchymal precursors from human embryonic stem cells. PLoS Med, Vol. 2, No. 6, e161. 1549-1676

Barberi, T.; Bradbury, M.; Dincer, Z.; Panagiotakos, G.; Socci, N.D. \& Studer, L. (2007). Derivation of engraftable skeletal myoblasts from human embryonic stem cells. Nat Med, Vol. 13, No. 5, 642-648. 1078-8956

Bi, W.; Deng, J.M.; Zhang, Z.; Behringer, R.R. \& de Crombrugghe, B. (1999). Sox9 is required for cartilage formation. Nat Genet, Vol. 22, No. 1, 85-89. 1061-4036

Bianco, P.; Robey, P.G. \& Simmons, P.J. (2008). Mesenchymal stem cells: revisiting history, concepts, and assays. Cell Stem Cell, Vol. 2, No. 4, 313-319. 1875-9777

Bigdeli, N.; Karlsson, C.; Strehl, R.; Concaro, S.; Hyllner, J. \& Lindahl, A. (2009). Coculture of human embryonic stem cells and human articular chondrocytes results in significantly altered phenotype and improved chondrogenic differentiation. Stem Cells, Vol. 27, No. 8, 1812-1821. 1549-4918

Brittberg, M.; Lindahl, A.; Nilsson, A.; Ohlsson, C.; Isaksson, O. \& Peterson, L. (1994). Treatment of deep cartilage defects in the knee with autologous chondrocyte transplantation. N Engl J Med, Vol. 331, No. 14, 889-895. 0028-4793

Darabi, R.; Gehlbach, K.; Bachoo, R.M.; Kamath, S.; Osawa, M.; Kamm, K.E.; Kyba, M. \& Perlingeiro, R.C. (2008). Functional skeletal muscle regeneration from differentiating embryonic stem cells. Nat Med, Vol. 14, No. 2, 134-143. 1546-170X

De Bari, C.; Dell'Accio, F. \& Luyten, F.P. (2001a). Human periosteum-derived cells maintain phenotypic stability and chondrogenic potential throughout expansion regardless of donor age. Arthritis Rheum, Vol. 44, No. 1, 85-95. 0004-3591

De Bari, C.; Dell'Accio, F.; Tylzanowski, P. \& Luyten, F.P. (2001b). Multipotent mesenchymal stem cells from adult human synovial membrane. Arthritis Rheum, Vol. 44, No. 8, 1928-1942. 0004-3591

Denker, A.E.; Nicoll, S.B. \& Tuan, R.S. (1995). Formation of cartilage-like spheroids by micromass cultures of murine C3H10T1/2 cells upon treatment with transforming growth factor-beta 1. Differentiation, Vol. 59, No. 1, 25-34. 0301-4681

Duprez, D.M.; Coltey, M.; Amthor, H.; Brickell, P.M. \& Tickle, C. (1996). Bone morphogenetic protein-2 (BMP-2) inhibits muscle development and promotes cartilage formation in chick limb bud cultures. Dev Biol, Vol. 174, No. 2, 448-452.

Evans, M.J. \& Kaufman, M.H. (1981). Establishment in culture of pluripotential cells from mouse embryos. Nature, Vol. 292, No. 5819, 154-156. 0028-0836

Fecek, C.; Yao, D.; Kacorri, A.; Vasquez, A.; Iqbal, S.; Sheikh, H.; Svinarich, D.M.; PerezCruet, M. \& Chaudhry, G.R. (2008). Chondrogenic derivatives of embryonic stem cells seeded into 3D polycaprolactone scaffolds generated cartilage tissue in vivo. Tissue engineering Part A, Vol. 14, No. 8, 1403-1413. 1937-3341

Fehling, H.J.; Lacaud, G.; Kubo, A.; Kennedy, M.; Robertson, S.; Keller, G. \& Kouskoff, V. (2003). Tracking mesoderm induction and its specification to the hemangioblast 
during embryonic stem cell differentiation. Development, Vol. 130, No. 17, 42174227.

Fukumoto, T.; Sperling, J.W.; Sanyal, A.; Fitzsimmons, J.S.; Reinholz, G.G.; Conover, C.A. \& O'Driscoll, S.W. (2003). Combined effects of insulin-like growth factor-1 and transforming growth factor-beta1 on periosteal mesenchymal cells during chondrogenesis in vitro. Osteoarthritis Cartilage, Vol. 11, No. 1, 55-64. 1063-4584

Fusaki, N.; Ban, H.; Nishiyama, A.; Saeki, K. \& Hasegawa, M. (2009). Efficient induction of transgene-free human pluripotent stem cells using a vector based on Sendai virus, an RNA virus that does not integrate into the host genome. Proc Jpn Acad Ser B Phys Biol Sci, Vol. 85, No. 8, 348-362. 1349-2896

Gadue, P.; Huber, T.L.; Nostro, M.C.; Kattman, S. \& Keller, G.M. (2005). Germ layer induction from embryonic stem cells. Exp Hematol, Vol. 33, No. 9, 955-964.

Gadue, P.; Huber, T.L.; Paddison, P.J. \& Keller, G.M. (2006). Wnt and TGF-beta signaling are required for the induction of an in vitro model of primitive streak formation using embryonic stem cells. Proc Natl Acad Sci U S A, Vol. 103, No. 45, 16806-16811. 00278424

Gikas, P.D.; Bayliss, L.; Bentley, G. \& Briggs, T.W. (2009). An overview of autologous chondrocyte implantation. J Bone Joint Surg Br, Vol. 91, No. 8, 997-1006. 0301-620X

Goldring, M.B.; Tsuchimochi, K. \& Ijiri, K. (2006). The control of chondrogenesis. J Cell Biochem, Vol. 97, No. 1, 33-44. 0730-2312

Gong, G.; Ferrari, D.; Dealy, C.N. \& Kosher, R.A. (2010). Direct and progressive differentiation of human embryonic stem cells into the chondrogenic lineage. J Cell Physiol, Vol. 224, No. 3, 664-671. 1097-4652

Gronthos, S.; Mankani, M.; Brahim, J.; Robey, P.G. \& Shi, S. (2000). Postnatal human dental pulp stem cells (DPSCs) in vitro and in vivo. Proc Natl Acad Sci U S A, Vol. 97, No. 25, 13625-13630. 0027-8424

Harkness, L.; Taipaleenmaki, H.; Mahmood, A.; Frandsen, U.; Saamanen, A.M.; Kassem, M. \& Abdallah, B.M. (2009). Isolation and differentiation of chondrocytic cells derived from human embryonic stem cells using dlk1/FA1 as a novel surface marker. Stem Cell Rev, Vol. 5, No. 4, 353-368. 1558-6804

Hoben, G.M.; Koay, E.J. \& Athanasiou, K.A. (2008). Fibrochondrogenesis in two embryonic stem cell lines: effects of differentiation timelines. Stem Cells, Vol. 26, No. 2, 422-430. $1549-4918$

Hoben, G.M.; Willard, V.P. \& Athanasiou, K.A. (2009). Fibrochondrogenesis of hESCs: growth factor combinations and cocultures. Stem Cells Dev, Vol. 18, No. 2, 283-292. 1557-8534

Hu, J.; Feng, K.; Liu, X. \& Ma, P.X. (2009). Chondrogenic and osteogenic differentiations of human bone marrow-derived mesenchymal stem cells on a nanofibrous scaffold with designed pore network. Biomaterials, Vol. 30, No. 28, 5061-5067. 1878-5905

Hwang, N.S.; Kim, M.S.; Sampattavanich, S.; Baek, J.H.; Zhang, Z. \& Elisseeff, J. (2006a). Effects of three-dimensional culture and growth factors on the chondrogenic differentiation of murine embryonic stem cells. Stem Cells, Vol. 24, No. 2, 284-291. 1066-5099 
Hwang, N.S.; Varghese, S.; Zhang, Z. \& Elisseeff, J. (2006b). Chondrogenic differentiation of human embryonic stem cell-derived cells in arginine-glycine-aspartate-modified hydrogels. Tissue Eng, Vol. 12, No. 9, 2695-2706. 1076-3279

Hwang, N.S.; Varghese, S. \& Elisseeff, J. (2008a). Derivation of chondrogenically-committed cells from human embryonic cells for cartilage tissue regeneration. PLoS ONE, Vol. 3, No. 6, e2498. 1932-6203

Hwang, N.S.; Varghese, S.; Lee, H.J.; Zhang, Z.; Ye, Z.; Bae, J.; Cheng, L. \& Elisseeff, J. (2008b). In vivo commitment and functional tissue regeneration using human embryonic stem cell-derived mesenchymal cells. Proc Natl Acad Sci U S A, Vol. 105, No. 52, 20641-20646. 1091-6490

Ikeda, T.; Kamekura, S.; Mabuchi, A.; Kou, I.; Seki, S.; Takato, T.; Nakamura, K.; Kawaguchi, H.; Ikegawa, S. \& Chung, U.I. (2004). The combination of SOX5, SOX6, and SOX9 (the SOX trio) provides signals sufficient for induction of permanent cartilage. Arthritis Rheum, Vol. 50, No. 11, 3561-3573. 0004-3591

Ishizaka, S.; Shiroi, A.; Kanda, S.; Yoshikawa, M.; Tsujinoue, H.; Kuriyama, S.; Hasuma, T.; Nakatani, K. \& Takahashi, K. (2002). Development of hepatocytes from ES cells after transfection with the HNF-3beta gene. Faseb J, Vol. 16, No. 11, 1444-1446. 15306860

Johansson, B.M. \& Wiles, M.V. (1995). Evidence for involvement of activin A and bone morphogenetic protein 4 in mammalian mesoderm and hematopoietic development. Mol Cell Biol, Vol. 15., No. 1., 141-151. 0270-7306

Johnstone, B.; Hering, T.M.; Caplan, A.I.; Goldberg, V.M. \& Yoo, J.U. (1998). In vitro chondrogenesis of bone marrow-derived mesenchymal progenitor cells. Exp Cell Res, Vol. 238, No. 1, 265-272.

Jukes, J.M.; Moroni, L.; van Blitterswijk, C.A. \& de Boer, J. (2008). Critical Steps toward a tissue-engineered cartilage implant using embryonic stem cells. Tissue engineering Part A, Vol. 14, No. 1, 135-147. 1937-3341

Jukes, J.M.; van Blitterswijk, C.A. \& de Boer, J. (2010). Skeletal tissue engineering using embryonic stem cells. J Tissue Eng Regen Med, Vol. 4, No. 3, 165-180. 1932-7005

Kaji, K.; Norrby, K.; Paca, A.; Mileikovsky, M.; Mohseni, P. \& Woltjen, K. (2009). Virus-free induction of pluripotency and subsequent excision of reprogramming factors. Nature, Vol. 458, No. 7239, 771-775. 1476-4687

Kawaguchi, J.; Mee, P.J. \& Smith, A.G. (2005). Osteogenic and chondrogenic differentiation of embryonic stem cells in response to specific growth factors. Bone, Vol. 36, No. 5, 758-769. 8756-3282

Keller, G. (2005). Embryonic stem cell differentiation: emergence of a new era in biology and medicine. Genes Dev, Vol. 19, No. 10, 1129-1155

Kim, J.H.; Do, H.J.; Yang, H.M.; Oh, J.H.; Choi, S.J.; Kim, D.K.; Cha, K.Y. \& Chung, H.M. (2005). Overexpression of SOX9 in mouse embryonic stem cells directs the immediate chondrogenic commitment. Exp Mol Med, Vol. 37, No. 4, 261-268. 12263613

Koay, E.J.; Hoben, G.M. \& Athanasiou, K.A. (2007). Tissue engineering with chondrogenically differentiated human embryonic stem cells. Stem Cells, Vol. 25, No. 9, 2183-2190. 1549-4918 
Koay, E.J. \& Athanasiou, K.A. (2008). Hypoxic chondrogenic differentiation of human embryonic stem cells enhances cartilage protein synthesis and biomechanical functionality. Osteoarthritis Cartilage. 1063-4584

Koay, E.J. \& Athanasiou, K.A. (2009). Development of Serum-Free, Chemically Defined Conditions for Human Embryonic Stem Cell-Derived Fibrochondrogenesis. Tissue Eng Part A. 1937-3341

Kramer, J.; Hegert, C.; Guan, K.; Wobus, A.M.; Mueller, P.K. \& Rohwedel, J. (2000). Embryonic stem cell-derived chondrogenic differentiation in vitro: activation by BMP-2 and BMP-4. Mech Dev, Vol. 92, No. 2, 193-205. 0925-4773

Kramer, J.; Hegert, C.; Hargus, G. \& Rohwedel, J. (2005a). Mouse ES cell lines show a variable degree of chondrogenic differentiation in vitro. Cell Biol Int, Vol. 29, No. 2, 139-146. 1065-6995

Kramer, J.; Klinger, M.; Kruse, C.; Faza, M.; Hargus, G. \& Rohwedel, J. (2005b). Ultrastructural analysis of mouse embryonic stem cell-derived chondrocytes. Anat Embryol, Vol. 210, No. 3, 175-185. 0340-2061

Kulyk, W.M.; Rodgers, B.J.; Greer, K. \& Kosher, R.A. (1989). Promotion of embryonic chick limb cartilage differentiation by transforming growth factor-beta. Dev Biol, Vol. 135, No. 2, 424-430.

Lee, G.; Kim, H.; Elkabetz, Y.; Al Shamy, G.; Panagiotakos, G.; Barberi, T.; Tabar, V. \& Studer, L. (2007). Isolation and directed differentiation of neural crest stem cells derived from human embryonic stem cells. Nat Biotechnol, Vol. 25, No. 12, 14681475. 1546-1696

Lee, H.J.; Yu, C.; Chansakul, T.; Varghese, S.; Hwang, N.S. \& Elisseeff, J.H. (2008). Enhanced chondrogenic differentiation of embryonic stem cells by coculture with hepatic cells. Stem Cells Dev, Vol. 17, No. 3, 555-563. 1547-3287

Levenberg, S.; Huang, N.F.; Lavik, E.; Rogers, A.B.; Itskovitz-Eldor, J. \& Langer, R. (2003). Differentiation of human embryonic stem cells on three-dimensional polymer scaffolds. Proc Natl Acad Sci U S A, Vol. 100, No. 22, 12741-12746. 0027-8424

Li, W.J.; Tuli, R.; Huang, X.; Laquerriere, P. \& Tuan, R.S. (2005). Multilineage differentiation of human mesenchymal stem cells in a three-dimensional nanofibrous scaffold. Biomaterials, Vol. 26, No. 25, 5158-5166. 0142-9612

Mackay, A.M.; Beck, S.C.; Murphy, J.M.; Barry, F.P.; Chichester, C.O. \& Pittenger, M.F. (1998). Chondrogenic differentiation of cultured human mesenchymal stem cells from marrow. Tissue Eng, Vol. 4, No. 4., 415-428.

Mahmood, A.; Harkness, L.; Schroder, H.D.; Abdallah, B.M. \& Kassem, M. (2010). Enhanced differentiation of human embryonic stem cells to mesenchymal progenitors by inhibition of TGF-beta/activin/nodal signaling using SB-431542. J Bone Miner Res, Vol. 25, No. 6, 1216-1233. 1523-4681

Martin, G.R. (1981). Isolation of a pluripotent cell line from early mouse embryos cultured in medium conditioned by teratocarcinoma stem cells. Proc Natl Acad Sci U S A, Vol. 78, No. 12, 7634-7638. 0027-8424

Mizuseki, K.; Sakamoto, T.; Watanabe, K.; Muguruma, K.; Ikeya, M.; Nishiyama, A.; Arakawa, A.; Suemori, H.; Nakatsuji, N.; Kawasaki, H.; Murakami, F. \& Sasai, Y. (2003). Generation of neural crest-derived peripheral neurons and floor plate cells 
from mouse and primate embryonic stem cells. Proc Natl Acad Sci U S A, Vol. 100, No. 10, 5828-5833.

Morikawa, S.; Mabuchi, Y.; Niibe, K.; Suzuki, S.; Nagoshi, N.; Sunabori, T.; Shimmura, S.; Nagai, Y.; Nakagawa, T.; Okano, H. \& Matsuzaki, Y. (2009). Development of mesenchymal stem cells partially originate from the neural crest. Biochem Biophys Res Commun, Vol. 379, No. 4, 1114-1119. 1090-2104

Moriya, T.; Wada, Y.; Watanabe, A.; Sasho, T.; Nakagawa, K.; Mainil-Varlet, P. \& Moriya, H. (2007). Evaluation of reparative cartilage after autologous chondrocyte implantation for osteochondritis dissecans: histology, biochemistry, and MR imaging. J Orthop Sci, Vol. 12, No. 3, 265-273. 0949-2658

Murphy, J.M.; Dixon, K.; Beck, S.; Fabian, D.; Feldman, A. \& Barry, F. (2002). Reduced chondrogenic and adipogenic activity of mesenchymal stem cells from patients with advanced osteoarthritis. Arthritis Rheum, Vol. 46, No. 3, 704-713. 0004-3591

Murry, C.E. \& Keller, G. (2008). Differentiation of embryonic stem cells to clinically relevant populations: lessons from embryonic development. Cell, Vol. 132, No. 4, 661-680

Nakagawa, T.; Lee, S.Y. \& Reddi, A.H. (2009). Induction of chondrogenesis from human embryonic stem cells without embryoid body formation by bone morphogenetic protein 7 and transforming growth factor beta1. Arthritis Rheum, Vol. 60, No. 12, 3686-3692. 0004-3591

Nakano, T.; Kodama, H. \& Honjo, T. (1994). Generation of lymphohematopoietic cells from embryonic stem cells in culture. Science, Vol. 265, No. 5175, 1098-1101.

Nakano, T.; Kodama, H. \& Honjo, T. (1996). In vitro development of primitive and definitive erythrocytes from different precursors. Science, Vol. 272, No. 5262, 722-724.

Nakayama, N.; Lee, J. \& Chiu, L. (2000). Vascular endothelial growth factor synergistically enhances bone morphogenetic protein-4-dependent lymphohematopoietic cell generation from embryonic stem cells in vitro. Blood, Vol. 95, No. 7, 2275-2283. 00064971

Nakayama, N.; Duryea, D.; Manoukian, R.; Chow, G. \& Han, C.Y. (2003). Macroscopic cartilage formation with embryonic stem-cell-derived mesodermal progenitor cells. J Cell Sci, Vol. 116, No. Pt 10, 2015-2028. 0021-9533

Nienhuis, A.W.; Dunbar, C.E. \& Sorrentino, B.P. (2006). Genotoxicity of retroviral integration in hematopoietic cells. Molecular therapy : the journal of the American Society of Gene Therapy, Vol. 13, No. 6, 1031-1049. 1525-0016

Nishikawa, S.; Goldstein, R.A. \& Nierras, C.R. (2008). The promise of human induced pluripotent stem cells for research and therapy. Nat Rev Mol Cell Biol, Vol. 9, No. 9, 725-729. 1471-0080

Nishikawa, S.-I.; Jakt, L.M. \& Era, T. (2007). Embryonic stem-cell culture as a tool for developmental cell biology. Nat Rev Mol Cell Biol, Vol. 8, No. 6, 502-507. 1471-0072

Nishikawa, S.I.; Nishikawa, S.; Hirashima, M.; Matsuyoshi, N. \& Kodama, H. (1998). Progressive lineage analysis by cell sorting and culture identifies FLK1+VEcadherin+ cells at a diverging point of endothelial and hemopoietic lineages. Development, Vol. 125, No. 9, 1747-1757.

Nostro, M.C.; Cheng, X.; Keller, G.M. \& Gadue, P. (2008). Wnt, activin, and BMP signaling regulate distinct stages in the developmental pathway from embryonic stem cells to blood. Cell Stem Cell, Vol. 2, No. 1, 60-71. 1934-5909 
Okita, K.; Nakagawa, M.; Hyenjong, H.; Ichisaka, T. \& Yamanaka, S. (2008). Generation of mouse induced pluripotent stem cells without viral vectors. Science, Vol. 322, No. 5903, 949-953. 1095-9203

Oldershaw, R.A.; Baxter, M.A.; Lowe, E.T.; Bates, N.; Grady, L.M.; Soncin, F.; Brison, D.R.; Hardingham, T.E. \& Kimber, S.J. (2010). Directed differentiation of human embryonic stem cells toward chondrocytes. Nat Biotechnol, Vol. 28, No. 11, 11871194. 1546-1696

Park, I.H.; Zhao, R.; West, J.A.; Yabuuchi, A.; Huo, H.; Ince, T.A.; Lerou, P.H.; Lensch, M.W. \& Daley, G.Q. (2008). Reprogramming of human somatic cells to pluripotency with defined factors. Nature, Vol. 451, No. 7175, 141-146. 1476-4687

Pittenger, M.F.; Mackay, A.M.; Beck, S.C.; Jaiswal, R.K.; Douglas, R.; Mosca, J.D.; Moorman, M.A.; Simonetti, D.W.; Craig, S. \& Marshak, D.R. (1999). Multilineage potential of adult human mesenchymal stem cells. Science, Vol. 284, No. 5411, 143-147.

Richardson, S.M.; Curran, J.M.; Chen, R.; Vaughan-Thomas, A.; Hunt, J.A.; Freemont, A.J. \& Hoyland, J.A. (2006). The differentiation of bone marrow mesenchymal stem cells into chondrocyte-like cells on poly-L-lactic acid (PLLA) scaffolds. Biomaterials, Vol. 27, No. 22, 4069-4078. 0142-9612

Richardson, S.M.; Hughes, N.; Hunt, J.A.; Freemont, A.J. \& Hoyland, J.A. (2008). Human mesenchymal stem cell differentiation to NP-like cells in chitosanglycerophosphate hydrogels. Biomaterials, Vol. 29, No. 1, 85-93. 0142-9612

Roberts, S.; Menage, J.; Sandell, L.J.; Evans, E.H. \& Richardson, J.B. (2009). Immunohistochemical study of collagen types I and II and procollagen IIA in human cartilage repair tissue following autologous chondrocyte implantation. Knee, Vol. 16, No. 5, 398-404. 1873-5800

Sakurai, H.; Era, T.; Jakt, L.M.; Okada, M.; Nakai, S.; Nishikawa, S. \& Nishikawa, S.I. (2006). In vitro modeling of paraxial and lateral mesoderm differentiation reveals early reversibility. Stem Cells, 575-586. 1066-5099

Shi, Y.; Desponts, C.; Do, J.T.; Hahm, H.S.; Scholer, H.R. \& Ding, S. (2008). Induction of pluripotent stem cells from mouse embryonic fibroblasts by Oct4 and Klf4 with small-molecule compounds. Cell Stem Cell, Vol. 3, No. 5, 568-574. 1875-9777

Smith, J.R.; Vallier, L.; Lupo, G.; Alexander, M.; Harris, W.A. \& Pedersen, R.A. (2008). Inhibition of Activin/Nodal signaling promotes specification of human embryonic stem cells into neuroectoderm. Dev Biol, Vol. 313, No. 1, 107-117. 1095-564X

Stadtfeld, M.; Nagaya, M.; Utikal, J.; Weir, G. \& Hochedlinger, K. (2008). Induced pluripotent stem cells generated without viral integration. Science, Vol. 322, No. 5903, 945-949. 1095-9203

Steinert, A.F.; Ghivizzani, S.C.; Rethwilm, A.; Tuan, R.S.; Evans, C.H. \& Noth, U. (2007). Major biological obstacles for persistent cell-based regeneration of articular cartilage. Arthritis Res Ther, Vol. 9, No. 3, 213. 1478-6362

Steventon, B.; Carmona-Fontaine, C. \& Mayor, R. (2005). Genetic network during neural crest induction: from cell specification to cell survival. Semin Cell Dev Biol, Vol. 16, No. 6, 647-654. 1084-9521

Sui, Y.; Clarke, T. \& Khillan, J.S. (2003). Limb bud progenitor cells induce differentiation of pluripotent embryonic stem cells into chondrogenic lineage. Differentiation, Vol. 71, No. 9-10, 578-585. 0301-4681 
Takahashi, K. \& Yamanaka, S. (2006). Induction of pluripotent stem cells from mouse embryonic and adult fibroblast cultures by defined factors. Cell, Vol. 126, No. 4, 663-676. 0092-8674

Takahashi, K.; Tanabe, K.; Ohnuki, M.; Narita, M.; Ichisaka, T.; Tomoda, K. \& Yamanaka, S. (2007). Induction of pluripotent stem cells from adult human fibroblasts by defined factors. Cell, Vol. 131, No. 5, 861-872. 0092-8674

Takakura, N.; Yoshida, H.; Ogura, Y.; Kataoka, H. \& Nishikawa, S. (1997). PDGFR alpha expression during mouse embryogenesis: immunolocalization analyzed by wholemount immunohistostaining using the monoclonal anti-mouse PDGFR alpha antibody APA5. J Histochem Cytochem, Vol. 45, No. 6, 883-893.

Takashima, Y.; Era, T.; Nakao, K.; Kondo, S.; Kasuga, M.; Smith, A.G. \& Nishikawa, S. (2007). Neuroepithelial cells supply an initial transient wave of MSC differentiation. Cell, Vol. 129, No. 7, 1377-1388. 0092-8674

Tanaka, M.; Jokubaitis, V.; Wood, C.; Wang, Y.; Brouard, N.; Pera, M.; Hearn, M.; Simmons, P. \& Nakayama, N. (2009). BMP inhibition stimulates WNT-dependent generation of chondrogenic mesoderm from embryonic stem cells. Stem Cell Res, Vol. 3, No. 23, 126-141. 1876-7753

Terraciano, V.; Hwang, N.; Moroni, L.; Park, H.B.; Zhang, Z.; Mizrahi, J.; Seliktar, D. \& Elisseeff, J. (2007). Differential response of adult and embryonic mesenchymal progenitor cells to mechanical compression in hydrogels. Stem Cells, Vol. 25, No. 11, 2730-2738. 1549-4918

Thomson, J.A.; Itskovitz-Eldor, J.; Shapiro, S.S.; Waknitz, M.A.; Swiergiel, J.J.; Marshall, V.S. \& Jones, J.M. (1998). Embryonic stem cell lines derived from human blastocysts. Science, Vol. 282, No. 5391, 1145-1147. 0036-8075

Toh, W.S.; Yang, Z.; Liu, H.; Heng, B.C.; Lee, E.H. \& Cao, T. (2007). Effects of culture conditions and bone morphogenetic protein 2 on extent of chondrogenesis from human embryonic stem cells. Stem Cells, Vol. 25, No. 4, 950-960. 1066-5099

Toh, W.S.; Guo, X.M.; Choo, A.B.; Lu, K.; Lee, E.H. \& Cao, T. (2009). Differentiation and enrichment of expandable chondrogenic cells from human embryonic stem cells in vitro. J Cell Mol Med, Vol. 13, No. 9B, 3570-3590. 1582-4934

Toh, W.S.; Lee, E.H.; Guo, X.M.; Chan, J.K.; Yeow, C.H.; Choo, A.B. \& Cao, T. (2010). Cartilage repair using hyaluronan hydrogel-encapsulated human embryonic stem cell-derived chondrogenic cells. Biomaterials, Vol. 31, No. 27, 6968-6980. 18785905

Tokalov, S.V.; Gruner, S.; Schindler, S.; Wolf, G.; Baumann, M. \& Abolmaali, N. (2007). Agerelated changes in the frequency of mesenchymal stem cells in the bone marrow of rats. Stem Cells Dev, Vol. 16, No. 3, 439-446. 1547-3287

Vats, A.; Bielby, R.C.; Tolley, N.; Dickinson, S.C.; Boccaccini, A.R.; Hollander, A.P.; Bishop, A.E. \& Polak, J.M. (2006). Chondrogenic differentiation of human embryonic stem cells: the effect of the micro-environment. Tissue Eng, Vol. 12, No. 6, 1687-1697. 1076-3279

Wallin, J.; Wilting, J.; Koseki, H.; Fritsch, R.; Christ, B. \& Balling, R. (1994). The role of Pax-1 in axial skeleton development. Development, Vol. 120, No. 5, 1109-1121. 0950-1991 
Wang, Y. \& Nakayama, N. (2009). WNT and BMP signaling are both required for hematopoietic cell development from human ES cells. Stem Cell Res, Vol. 3, No. 2-3, 113-125. 1876-7753

Wang, Y.; Umeda, K. \& Nakayama, N. (2010). Collaboration between WNT and BMP signaling promotes hemoangiogenic cell development from human fibroblastderived iPS cells. Stem Cell Res, Vol. 4, No. 3, 223-231. 1876-7753

Wiles, M.V. \& Johansson, B.M. (1997). Analysis of factors controlling primary germ layer formation and early hematopoiesis using embryonic stem cell in vitro differentiation. Leukemia, Vol. 11 Suppl 3, 454-456.

Woltjen, K.; Michael, I.P.; Mohseni, P.; Desai, R.; Mileikovsky, M.; Hamalainen, R.; Cowling, R.; Wang, W.; Liu, P.; Gertsenstein, M.; Kaji, K.; Sung, H.K. \& Nagy, A. (2009). piggyBac transposition reprograms fibroblasts to induced pluripotent stem cells. Nature, Vol. 458, No. 7239, 766-770. 1476-4687

Wong, C.E.; Paratore, C.; Dours-Zimmermann, M.T.; Rochat, A.; Pietri, T.; Suter, U.; Zimmermann, D.R.; Dufour, S.; Thiery, J.P.; Meijer, D.; Beermann, F.; Barrandon, Y. \& Sommer, L. (2006). Neural crest-derived cells with stem cell features can be traced back to multiple lineages in the adult skin. J Cell Biol, Vol. 175, No. 6, 10051015. 0021-9525

Xu, C.; Jiang, J.; Sottile, V.; McWhir, J.; Lebkowski, J. \& Carpenter, M.K. (2004). Immortalized fibroblast-like cells derived from human embryonic stem cells support undifferentiated cell growth. Stem Cells, Vol. 22, No. 6, 972-980. 1066-5099

Yamaguchi, T.P.; Dumont, D.J.; Conlon, R.A.; Breitman, M.L. \& Rossant, J. (1993). flk-1, an flt-related receptor tyrosine kinase is an early marker for endothelial cell precursors. Development, Vol. 118, No. 2, 489-498.

Yoo, J.U.; Barthel, T.S.; Nishimura, K.; Solchaga, L.; Caplan, A.I.; Goldberg, V.M. \& Johnstone, B. (1998). The chondrogenic potential of human bone-marrow-derived mesenchymal progenitor cells. J Bone Joint Surg Am, Vol. 80, No. 12, 1745-1757. 0021-9355

Yu, J.; Vodyanik, M.A.; Smuga-Otto, K.; Antosiewicz-Bourget, J.; Frane, J.L.; Tian, S.; Nie, J.; Jonsdottir, G.A.; Ruotti, V.; Stewart, R.; Slukvin, II \& Thomson, J.A. (2007). Induced pluripotent stem cell lines derived from human somatic cells. Science, Vol. 318, No. 5858, 1917-1920. 1095-9203

Yu, J.; Hu, K.; Smuga-Otto, K.; Tian, S.; Stewart, R.; Slukvin, II \& Thomson, J.A. (2009). Human induced pluripotent stem cells free of vector and transgene sequences. Science, Vol. 324, No. 5928, 797-801. 1095-9203

Yusa, K.; Rad, R.; Takeda, J. \& Bradley, A. (2009). Generation of transgene-free induced pluripotent mouse stem cells by the piggyBac transposon. Nat methods, Vol. 6, No. 5, 363-369. 1548-7105

Zhou, Y. \& Snead, M.L. (2008). Derivation of cranial neural crest-like cells from human embryonic stem cells. Biochem Biophys Res Commun, Vol. 376, No. 3, 542-547. 10902104

Zuk, P.A.; Zhu, M.; Ashjian, P.; De Ugarte, D.A.; Huang, J.I.; Mizuno, H.; Alfonso, Z.C.; Fraser, J.K.; Benhaim, P. \& Hedrick, M.H. (2002). Human adipose tissue is a source of multipotent stem cells. Molecular biology of the cell, Vol. 13, No. 12, 4279-4295. 1059-1524 
zur Nieden, N.I.; Kempka, G.; Rancourt, D.E. \& Ahr, H.J. (2005). Induction of chondro-, osteo- and adipogenesis in embryonic stem cells by bone morphogenetic protein-2: effect of cofactors on differentiating lineages. BMC Dev Biol, Vol. 5, 1. 1471-213X 


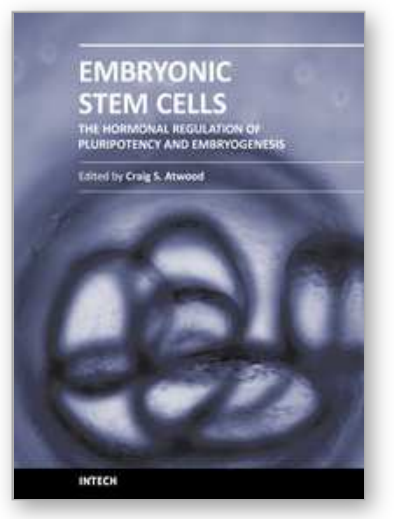

\section{Embryonic Stem Cells: The Hormonal Regulation of Pluripotency and Embryogenesis}

Edited by Prof. Craig Atwood

ISBN 978-953-307-196-1

Hard cover, 672 pages

Publisher InTech

Published online 26, April, 2011

Published in print edition April, 2011

Pluripotency is a prerequisite for the subsequent coordinated differentiation of embryonic stem cells into all tissues of the body. This book describes recent advances in our understanding of pluripotency and the hormonal regulation of embryonic stem cell differentiation into tissue types derived from the ectoderm, mesoderm and endoderm.

\section{How to reference}

In order to correctly reference this scholarly work, feel free to copy and paste the following:

Naoki Nakayama and Katsutsugu Umeda (2011). From Pluripotent Stem Cells to Lineage-Specific Chondrocytes: Essential Signalling and Cellular Intermediates, Embryonic Stem Cells: The Hormonal Regulation of Pluripotency and Embryogenesis, Prof. Craig Atwood (Ed.), ISBN: 978-953-307-196-1, InTech, Available from: http://www.intechopen.com/books/embryonic-stem-cells-the-hormonal-regulation-ofpluripotency-and-embryogenesis/from-pluripotent-stem-cells-to-lineage-specific-chondrocytes-essentialsignalling-and-cellular-inter

\section{INTECH}

open science | open minds

\section{InTech Europe}

University Campus STeP Ri

Slavka Krautzeka 83/A

51000 Rijeka, Croatia

Phone: +385 (51) 770447

Fax: +385 (51) 686166

www.intechopen.com

\section{InTech China}

Unit 405, Office Block, Hotel Equatorial Shanghai

No.65, Yan An Road (West), Shanghai, 200040, China

中国上海市延安西路 65 号上海国际贵都大饭店办公楼 405 单元

Phone: +86-21-62489820

Fax: +86-21-62489821 
(C) 2011 The Author(s). Licensee IntechOpen. This chapter is distributed under the terms of the Creative Commons Attribution-NonCommercialShareAlike-3.0 License, which permits use, distribution and reproduction for non-commercial purposes, provided the original is properly cited and derivative works building on this content are distributed under the same license. 